Fossil

Enengy

Phogram

\title{
Fossil Energy Program Progress Report for April 1978
}

L. E. McNeese

\section{OAK RIDGE NATIONAL LABORATORY} OPERATED BY UNION CARBIDE CORPORATION - FOR THE DEPARTMENT OF ENERGY 


\section{DISCLAIMER}

This report was prepared as an account of work sponsored by an agency of the United States Government. Neither the United States Government nor any agency Thereof, nor any of their employees, makes any warranty, express or implied, or assumes any legal liability or responsibility for the accuracy, completeness, or usefulness of any information, apparatus, product, or process disclosed, or represents that its use would not infringe privately owned rights. Reference herein to any specific commercial product, process, or service by trade name, trademark, manufacturer, or otherwise does not necessarily constitute or imply its endorsement, recommendation, or favoring by the United States Government or any agency thereof. The views and opinions of authors expressed herein do not necessarily state or reflect those of the United States Government or any agency thereof. 


\section{DISCLAIMER}

Portions of this document may be illegible in electronic image products. Images are produced from the best available original document. 
Printed in the United States of America. Available from National Technical Information Service

U.S. Department of Commerce

5285 Port Royal Road, Springfield, Virginia 22161

Price: Printed Copy $\$ \in .00$, Microfiche $\$ 3.00$

This report was prepared as an account of work sponsored by an agency of the United States Government. Neither the United States Government nor any agency thereof, nor any of their employees, contractors, subcontractors, or their employees, makes any warranty, express or implied, nor assumes any legal liability or responsibility for any third party's use or the results of such use of any information, apparatus, product or process disclosed in this report, nor represents that its use by such third party would not infringe privately owned rights. 
Contract No. W-7405-eng-26

FOSSIL ENERGY PROGRAM

PROGRESS REPORT FOR APRIL 1978

L. E. McNeese

Program Director

Date Published - June, 1978

This report was prepared as an account of work sponsored by the United States Government. Neither the United States nor the United States Department of Energy, nưs any of thelr employees, nor any of their contractors, subcontractors, or their employees, makes any wartanty, express or implied, or assumes makes

liability or responsibility for the accuracy

or usefulness of any intormation, apparatus, product ox

process disclosed, or represents, that its use would not

process disclosed. or represents,
infringe privalely owned rights.

OAK RIDGE NATIONAL LABORATORY

Oak Ridge, Tennessee 37830

operated by

UNION CARBIDE CORPORATION

for the

DEPARTMENT OF ENERGY 


\section{THIS PAGE}

WAS INTENTIONALLY

LEFT BLANK 
CONTENTS

Page

ABSTRACT . . . . . . . . . . . . . . . . . . . 1

1. Summary . . . . . . . . . . . . . . . . 1

2. COAL CONVERSION PROCESS DEVELOPMENT . . . . . . . . . . . . . 4

2.1 Hydrocarbonization Research . . . . . . . . . . . . 4

2.2. Physical Properties of Coal Liquids . . . . . . . . . 6

2.3 Coal Slurry Preheaters . . . . . . . . . . . . 15

2.4 New Liquefaction Techniques . . . . . . . ... 16

2.5 In-plant Environmental Monitors ............ 18

2.6 Experimental Engineering Support of In Situ 20

Gasification Processes .............. 20

2.7 References for Section 2............. 32

3. MATERIALS ENGINEERING ................... . . . 33

3.1 Pressure Vessel and Piping Materials . . . . . . . . 33

3.2 Inspection Techniques for Wear- and
Process-Resistant Coatings . . . . . . . . . . . . 34

3.3 Fossil Energy Welding and Cladding Program . . . . . . 35

3.4 Fireside Corrosion of Atmospheric-Fluidized
Bed Combustor Tubes. . . . . . . . . . . . . 35

3.5 Failure Analysis and Prevention . . . . . . . . 35

4. ALKALI METAL VAPOR TOPPING CYCLES . . . . . . . . . . . . 37

4.1 Gas-Fired Potassium Boiler . . . . . . . . . . . . 37

5. COAL EQUIPMENT TEST PROGRAM . . . . . . . . . . . . . . . . 39

5.1 Critical Equipment for Demo Plants........... 39

5.2 Coal Feeder Test Program . . . ........... 40

5.3 Survey of Industrial Capability for Coal

Handling Equipment . . . . . . . . . . . . . . 40

5.4 Coal/Solids Handling and Feed Systems Program Plan . . . 41

6. ATMOSPHERIC FLUIDIZED BED COAL COMBUSTOR FOR

COGENERATION (AFB CCC) . . . . . . . . . . . . . . . . . 42

6.1 Combustor Specifications . . . . . . . . . . . . 42

6.2 System Design . . . . . . . . . . . . . . . 42

6.3 Coal Feeder Development . . . . . . . . . . . . 42

6.4 Materials Testing . . . . . . . . . . . . . 42

7. ENGINEERING STUDIES AND TECHNICAL SUPPORT . . . . . . . . 43

7.1. Process Modeling . . . . . . . . . . . . . . . . 43

7.2 Synthetic Fuels Process Research Digest . . . . . . . . 44

7.3 Survey of Industrial Coal Conversion Equipment Capabilities................. 45

7.4 Flash Hydropyrolysis ................. 47

7.5 Hot Gas Purification Processes . . . . . . . . . . . 47 
7.6 State-of-the-Art Review of Heat Recovery

Processes...................... 4 48

7.7 Assessment of a Moving Bed System for Cleanup of Raw Gasifier Gas . . . . . . . . . . . . . . 48

7.8 Technical/Economic Assessment of Hydrogen Production by the Steam/Molten Iron Process . . . . . . . 49

7.9 A Study of Effluent Control Technologies for Hydrocarbon and Carbon Monoxide Emissions from Coal Conversion Plants . . . . . . . . . . . . . . . 49

7.10 Environmental Controls for Low-Btu Gasification . . . . 50

7.11 Support of the Office of Initial Operations (OIO) . . . . 51

8. PROCESS AND PROGRAM ANALYSIS . . . . . . . . . . . . 53

8.1 Low Btu Coal Gasification . . . . . . . . . . . . . 53

8.2 Direct Combustion .. . . . . . . . . . . . . . . 54

8.3 Advanred Power Conversion Systems . . . . . . . . . . 55

8.4 In Situ Coal Gasification . . . . . . . . . . . . . 36

8.5 Coal Beneficiation ................. 56

8.6 Gas Cleanup Studies .................. 57

8.7 HYGAS Modeling . . . . . . . . . . . . . . 57

8.8 Liquefaction .. . . . . . . . . . . . . . . . 59

8.9 High Btu Gas . . . . . . . . . . . . . . . . . . . 60

8.10 Comparative Cost Estimates of Five Coal

Utilization Processes.............. . 60

9. FOSSIL ENERGY ENVIRONMENTAL PROJECT . . . . . . . . . . . 62

9.1 Stored Solids Study . . . . . . . . . . . . . . . . . 62

9.2 Environmental Monitoring Handbook .. . . . . . . . . 63

9.3 Technical. Assistance ................ 63

10. MAGNETIC BENEFICIATION OF DRY PULVERIZED COAL . . . . . . . 10.1 Objective . . . . . . . . . . . . . . . . . . . . . 10.2 Status Summary. . . . . . . . . . . . . . . .

11. ATMOSPHERIC FLUIDIZED BED COMBUSTION DEMONSTRATION PLANT . . . 66

11.1 Engineering Support . . . . . . . . . . . . . . . . 66

11.2 Technology Assessment . . . . . . . . . . . . . 66 
PREVIOUS REPORTS IN THIS SERIES

ORNL/TM-5044, Progress Report for August 1974

ORNL/TM-5045, Progress Report for September 1974

ORNL/TM-5046, Progress Report for October 1974

ORNL/TM-4787, Progress Report for November 1974

ORNL/TM-4796, Progress Report for December 1974

ORNL/TM-4850, Progress Report for January 1975

ORNL/TM-4873, Progress Report for February 1975

ORNL/TM-4892, Progress Report for March 1975

ORNL/TM-4946, Progress Report for April 1975

ORNL/TM-4966, Progress Report for May 1975

ORNL/TM-5010, Progress Report for June 1975

ORNL/TM-5037, Progress Report for July 1975

ORNL/TM-5092, Progress Report for August 1975

ORNL/TM-5124, Progress Report for September 1975

ORNL/TM-5186, Progress Report for October 1975

ORNL/TM-5214, Progress Report for November 1975

ORNL/TM-5246, Progress Report for December 1975

ORNL/TM-5301, Progress Report for January 1976

ORNL/TM-5321; Progress Report for February 1976

ORNL/TM-5430, Progress Report for March 1976

ORNL/TM-5479, Progress Report for April 1976

ORNL/TM-5532, Progress Report for May 1976

ORNL/TM-5595, Progress Report for June 1976

ORNL/TM-5611, Progress Report for July 1976

ORNL/TM-5654, Progress Report for August 1976

ORNL/TM-5674, Progress Report for September 1976

ORNL/TM-5717, Progress Report for October 1976

ORNL/TM-5752, Progress Report for November 1976

ORNL/TM-5770, Progress Report for December 1976

ORNL/TM-581.9, Progress Report for January 1977

ORNL/TM-5858, Progress Report for February 1977

ORNL/TM-5883, Progress Report for March 1977

ORNL/TM-5932, Progress Report for April 1977

ORNL/TM-5980, Progress Report for May 1977

ORNL/TM-6003, Progress Report for June 1977

ORNL/TM-6038, Progress Report for July 1977

ORNL/TM-6066, Progress Report for August 1977

ORNL/TM-6104, Progress Report for September 1977

ORNL/TM-6137, Progress Report for October 1977

ORNL/TM-6217, Progress Report for November 1977

ORNL/TM-6262, Progress Report for December 1977

ORNL/TM-6274, Progress Report for January 1978

ORNL/TM-6329, Frugress Report for February 1978

ORNL/TM-6385, Progress Report for March 1978 


\section{ABSTRACT}

This report - the forty fifth of a series - is a compendium of monthly progress reports for the ORNL Research and development programs that are in support of the increased utilization of coal and other fossil fuel alternatives to oil and gas as sources of clean energy. The projects reported this month include those for coal conversion process development, materials engineering, alkali metal vapor topping cycles, a coal equipment test program, an AFB coal combustor for cogeneration (CCC), engineering and support studies, process and program assistance, envịronmental assessment studies, magnetic beneficiation, and AFBC demonstration plant.

\section{Summary}

L. E. McNeese

Highlights of our progress in April are as follows:

Hydrocarbonization - The bench-scale hydrocarbonization reactor has been modified to increase the residence time of the coal in the draft tube threefold. This will permit more complete devolatilization of the coal in the draft tube and should alleviate caking problems when untreated bituminous coal is hydrocarbonized in the next planned experiment $\mathrm{HC}-27$.

Physical Properties of Coal Liquids - A new project has been initiated to measure the viscosity, density, heat capacity, and thermal conductivity of rnal-derivad liquids at process cunditions up to 4300 psi and $1000^{\circ} \mathrm{F}$.

Coal Slurry Preheaters - This project will evaluate experimentally the rheological and heat transfer characteristics of flowing coal/solvent/ hydrogen mixtures as they are preheated to reactor inlet conditions.

New Liquefaction Techniques - This new project will attempt to exploit recent advances in coal chemistry for possible liquefaction techniques. Initial experiments focus on ionic hydrogenation chemistry and HeredyNelıwrth depolymerization.

In-Plant Environmental Monitors - Two portable detectors will be designed, fabricated, and field tested for spotting polynuclear aromatic hydrocarbon contamination on work area surfaces. A laboratory prototype has successfully detected 10 nanogram quantities of surface contamination. 
In-Situ Gasification - The recent series of block pyrolysis experiments with lignite coals have been continued with experiment BP2-47. Previous results have been analyzed to evaluate the use of ethane concentration as a measure of pyrolysis reactions in field tests and to estimate the effective thermal conductivity of dried, unpyrolyzed coal.

Materials Engineering - Specimens to determine fracture toughness and tensile properties of $21 / 4 \mathrm{Cr}-1$ Mo in. thick sections are being prepared in several heat-treated conditions. X-ray fluorescence sensitivity tests indicate the technique has borderline sensitivity for 0.10 in. thick CoCrAIY. Examination of (AFBC) heat exchanger tubes that were exposed for $1500 \mathrm{hrs}$ is complete. Metallographic examination of samples removed from the Rivesville AFBC by Foster Wheeler is in progress.

Alkali Metal Vapor Topping Cycles - Installation of the mixing tee was completed and operation of the boiler was resumed. Plugging of the condenser argon vent line and a value in the fill line necessitated the installation of a 100-mesh screen filter in the fill line and additional heaters on the argon vent liner to reduce plugging problems.

Coal Equipment Test Program - Four tentative test loups were defined for testing components. The COGAS process simulation work was finished. Trips were made to obtain information for the coal feeder test programs. A draft of the criteria for the conceptual designs of commercial coal handling equipment was completed. A comprehensive program plan is being developed to improve coal/solids handling and feed systems.

Atmospheric Fluidized Bed Coal Combustor for Cogeneration - A test of the coal feed system with limestone was conducted. Excellent results were obtained over the entire feed rate range and expanded bed height.

Process Modeling - Revised versions of the physical properties and material balance programs were recelved from Purdue. Discussions with Lehigh to conduct a short computer course were held. A Fortran program simulating a COGAS gasifier was completed.

Synthetic Fuels Process Research Digest - Work on the Digest has been halted pending review of articles by DOE-FE.

Surveys of Industrial Coal Conversion Equipment Capabilities Contacts with industry to obtain equipment information continues. netailed information was obtained on the Grayloc connector which could be useful fnr slurry service. Forms to obtain information on let-down values, expansion joints, and mechanical connectors are ready for mall $\perp_{11 y}$ lo manufacturers. Some overview comments are given on information obtained for pumps, compressors, expanders, solids handling, valves, heat recovery, and cyclones. 
Environmental Controls for Low Btu Gasification - Some difficulty has been encountered with the waste water treating processes. This is due to the lack of established standards on concentration of contaminants and performance of waste water treating processes for treating coal waste water.

Low Btu Coal Gasification - Work continues on a report summarizing 99 processes which were surveyed.

Direct Combustion - A technical and economic assessment report on the factors restricting use of coal is being reviewed by its authors and industrial representatives.

Advanced Power Conversion Systems - Draft reports have been prepared covering eleven systems or components with respect to their basic R\&D status.

In Situ Coal Gasification - Equipment sizing calculations were completed for all major process units of the in situ syngas-to-gasoline facility. Contract negotiations with Davy Powergas, Inc. continues for obtaining design and rust data for the methanol synthesis plant.

Hygas Modeling - Work continues on developing a computer model of the Hygas gasifier. Some problems are being. encountered in obtaining accurate data of some of the HYGAS processes.

Fossil Energy Environmental Project - Efforts continue to obtain waste from various processes such as Lurgi, Cogas, and SRC. Because of the unavailability of large quantities of waste, the lysimeter program will be scaled down. Investigation continues on leachate from coal storage piles.

Magnetic Beneficiation of Dry Pulverized Coal - Results are reported on three coals pulverized by different processes. It appears that the more finely the coal is crushed, the higher the percentage of inorganic material released.

AFBC Demonstration Plant - Review of the preliminary design and cost estimates for the demonstration unit from three boller manufactures, $B \& W$, FCC, and CE, is being made. The comparative analysis of the three designs will provide a point-by-point evaluation of all three design approaches. 


\title{
2. COAL CONVERSION DEVELOPMENT
}

\author{
H. D. Cochran, Jr.
}

Coal conversion development activities are carried out in the Chemical Technology. Division. Th1s section discusses five projects conducted for the Division of Coal Conversion -- Hydrocarbonization Research, Physical Properties of Coal Liquids, Coal Slurry Preheaters, New Liquefaction Techniques, and In-Plant Environmental Monitors -and one project conducted for the Division of Oil, Gas, Shale, and In-Situ Technology -- Experimental Engineering Support for In-Situ Gasification Processes.

\subsection{Hydrocarbonization Research}

E. L. Youngblood, J. Beams, and J. C. Rose

Work accomplished. During April we completed sampling and cleanup of the system after run $\mathrm{HC}-26$ and began preparing for the next run $(\mathrm{HC}-27)$. A 5-ft section has been added to the reactor to increase the length of the fluid-bed section. Most of the Illinois No. 6 coal has been prepared for the run. Some of the analytical data for run HC-26 have been received and are presented in this report.

Following run $\mathrm{HC}-26$ the reactor was removed from the system and cut apart 3 inches above the bottom flange. A 5-ft section of 4-in.-sched 80 pipe was welded between the two sections to increase the overall length of the reactor from 60 inches to 120 inches as shown in Fig. 2.1. The modification will increase the length of the draft tube from 29. inches to 89 inches. Based on the normal gas feed rate to the draft tube, the residence t1me in the draft tube will be 1ncreased from about $0.7 \mathrm{sec}$. to $2.3 \mathrm{sec}$. The actual residence time is somewhat less because of bypassing of gas from the downcomer region. Run HC-27 will be made with Illinois No. 6 coal to determine if the increased residence time in the draft tube will devolatilize the coal sufficiently to eliminate the problem of caking in the downcomer region that was experienced in previous runs with untreated caking coal.

Electrical heaters and thermocouples have been installed on the new reactor section. Further work w1ll be required to install the vessel, connect the electrical wiring and piping, insulate, and perform a pressure test before the system will be ready for operation.

The seals on the scrubber pump are being replaced before the next run. The pump has given good service during the past 5 runs; however, during run $\mathrm{HC}-26$ there was 1ncreased seal leakage, so the seals are being replaced as a precautionary measure. 


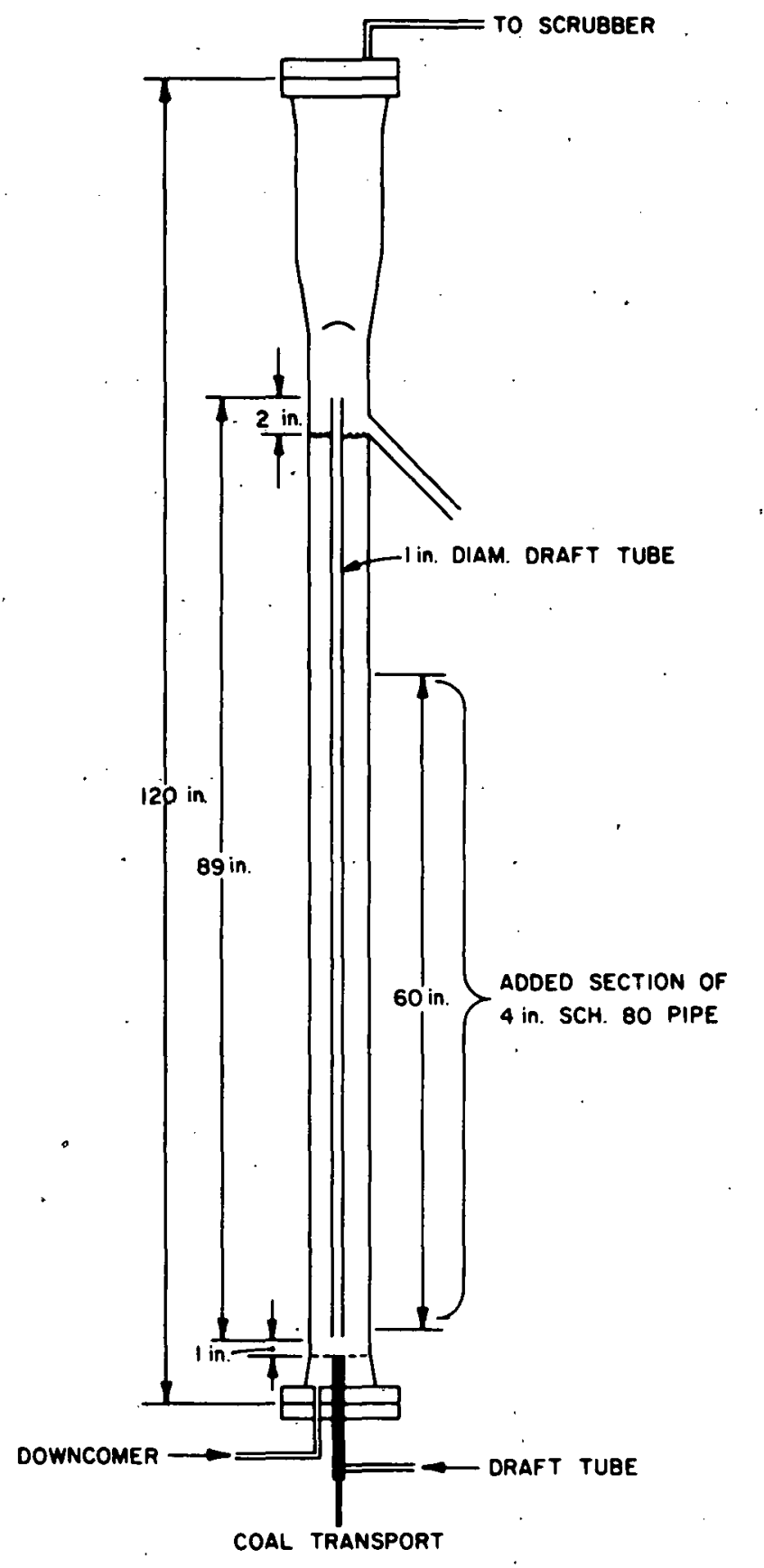

Fig. 2.1. Revised hydrocarbonization reactor. 
We have begun grinding and sieving coal and preparing the system for the next run. Filters in the cold trap have been replaced, and the pressure control valve has been cleaned. The gas chromatograph has been calibrated using a second standard gas of approximately the same composition as the off-gas from a run. Results using the second standard gas are in good agreement with the original calibration with the exception that the new calibration gas gives slightly higher values for ethane.

Some of the analytical results have been received from run $\mathrm{HC}-26$ which was made using Illinois No. 6 coal that was pretreated with $\mathrm{Na}_{2} \mathrm{CO}_{3}$ and $\mathrm{CaO}$ at atmospheric pressure. We do not yet have all the data neces 3 sary for determining material balances and oil yields; however, preliminary results indicate that the oil yleld will be less than that achieved in some of the other runs made under similar operating conditions. Evidently a considerable amount of the fine $\mathrm{CaO}$ and $\mathrm{Na}_{2} \mathrm{CO}_{3}$ particles used to treat the coal passed through the cyclone during the run and collected in the scrubbcr along with the oil product. The presence of solids containing carbonate has caused complications in soine of the analytical procedures for carbon determination.

Properties and composition of o1l from run $\mathrm{HC}-26$ that was centrifuged to remove water and solids is shown in Table 2.1. The properties of oil from runs $\mathrm{HC}-24$ and $\mathrm{HC}-25$ are shown in the table for comparison. The simulated boiling point curve for HC-26 product is shown in Fig. 2.2. The composition of the effluent gas from run HC-26 is given in Table 2.2.

Work forecast. Modification and checkout of the system for operation with the longer reactor will continue. Run $\mathrm{HC}-27$ is scheduled to be made near the end of May using Illinois No. 6 coal in the modified rcastor.

\subsection{Physical Properties of Coal Liqu1ds}

G. E. Oswald and H. D. Cochran, Jr.

This is the first report on a new project which was initiated during the month of April. As an introduction to the project this report includes excerpts from the work statement for the project.

Inowledge of the physical properties (e.g., viscosity, density, thermal conductivity, and heat capacicy) of conl liquids under process conditions is essential for proper design of heat transfer equipment, preheaters, reactors, separation units, and process piping systems in liquefaction processes. The high hydrogen pressure--high temperature conditions present in coal-solvent slurry liquefaction and hydroprocessing schemes, as high as $4500 \mathrm{psig}$ and $1000^{\circ} \mathrm{F}$, prevent measurement of physical properties of the process fluids with conventional instruments. Physical properties may be strongly influenced by the effect of dissolved 


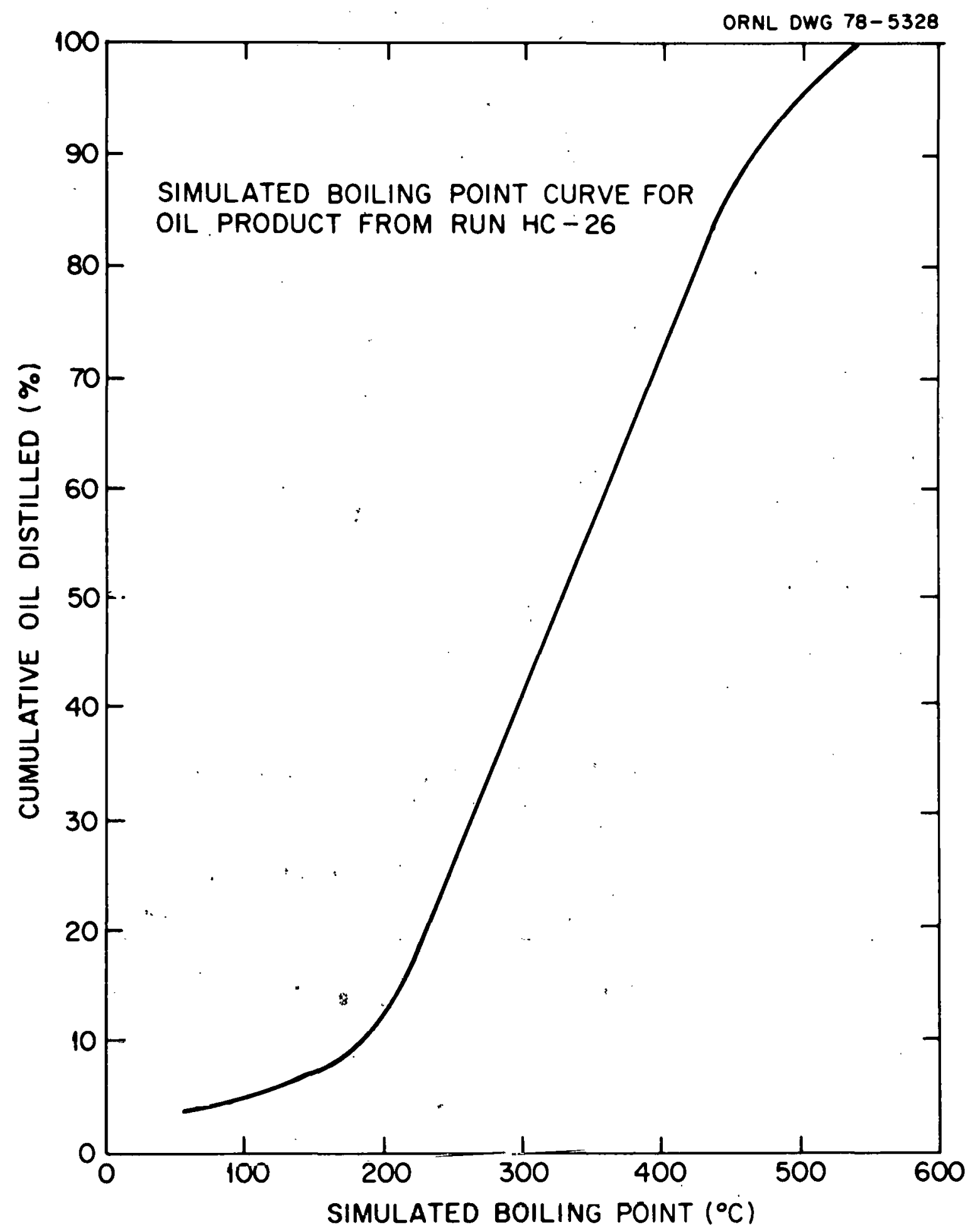

Fig. 2.2. Simulated boiling point curve for oil product from run HC-26. 
Table 2.1. Properties and composition of oil from runs $\mathrm{HC}-24, \mathrm{HC}-25$ and $\mathrm{HC}-26$.

\begin{tabular}{|c|c|c|c|}
\hline & $\begin{array}{c}\text { Run } \mathrm{HC}-26 \\
\left(\mathrm{Na}_{2} \mathrm{CO}_{3}-\mathrm{CaO}\right. \\
\text { treated } \\
\text { IIIInois No. 6) }\end{array}$ & $\begin{array}{c}\text { Run } \mathrm{HC}-24 \\
\quad\left(\mathrm{Na}_{2} \mathrm{CO}_{3}\right. \\
\text { treated } \\
\text { Illinois No. 6) }\end{array}$ & $\begin{array}{c}\text { Run HC-25 } \\
\text { Wyodak }\end{array}$ \\
\hline Specific gravity & 1.07 & 1.1 & 1.02 \\
\hline \multicolumn{4}{|l|}{ Viscosity (cs) } \\
\hline $\begin{array}{l}\text { at } 100^{\delta} \mathrm{F} \\
\text { at } 212^{n} \mathrm{~F}\end{array}$ & $\begin{array}{l}50 \\
3.6\end{array}$ & 120 & '36 \\
\hline \multicolumn{4}{|l|}{ Composition (\%) } \\
\hline $\begin{array}{l}\text { Moisture } \\
\text { Ash } \\
\text { Carbon (maf) } \\
\text { Hydrogen (maf) } \\
\text { Nitrogen (maf) } \\
\text { Sulfur (maf) } \\
\text { Oxygen (by difference) }\end{array}$ & $\begin{array}{l}0.9 \\
0.06 \\
87.1 \\
7.6 \\
1.3 \\
1.2 \\
2.8\end{array}$ & $\begin{array}{r}6.8 \\
0.7 \\
85.8 \\
7.2 \\
1.2 \\
1.5 \\
4.3\end{array}$ & $\begin{array}{r}5.7 \\
0.3 \\
84.9 \\
8.3 \\
1.0 \\
0.4 \\
5.4\end{array}$ \\
\hline
\end{tabular}

Table 2.2. HC-26 effluent gas composition at steady state-300 psig, $1055^{\circ} \mathrm{F}$ at 1000 on $3 / 28 / 78$.

\begin{tabular}{cccc}
\hline Composition & $\begin{array}{c}\text { Effluent flow } \\
\text { rate (scfm) }\end{array}$ & $\begin{array}{c}\text { Composition } \\
(\%)\end{array}$ & $\begin{array}{c}\mathrm{H}_{2} \text { and } \mathrm{N}_{2} \text {-free } \\
\text { composition (\%) }\end{array}$ \\
\hline $\mathrm{CH}_{4}$ & 0.188 & 0.92 & 60.2 \\
$\mathrm{C}_{2}$ & 0.042 & 0.21 & 1.3 .6 \\
$\mathrm{C}_{3}$ & 0.008 & 0.04 & 2.5 \\
$\mathrm{CO}^{2}$ & 0.061 & 0.31 & 20.2 \\
$\mathrm{CO}_{2}$ & 0.009 & 0.05 & 3.0 \\
$\mathrm{H}_{2} \mathrm{~S}^{\mathrm{a}}$ & 0.001 & 0.007 & 0.5 \\
$\mathrm{H}_{2}$ & 19.00 & 93.6 & \\
$\mathrm{~N}_{2}$ & 0.99 & 4.89 & \\
\hline
\end{tabular}

${ }^{a}$ Near low limit of sensitivity 
hydrogen and/or by the effects of ongoing hydrogenation reactions; therefore, flowing stream measurements are essential, and the test fluid must be quenched, sampled, and chemically characterized to provide a basis for ultimately correlating physical properties with chemical composition and physical conditions.

The objectives of this work are as follows:

1. Determine viscosity, density, heat capacity, and thermal conductivity of various available intermediate and product streams from SRC, H-Coal, and other processes as a function of temperature and hydrogen pressure.

2. Determine viscosity, density, heat capacity, and thermal conductivity of coal liquids under processing conditions, i.e., preheating, coal-solvent slurry dissolution, and hydroprocessing. Determine dependence of these liquid physical properties on degree of conversion and chemical characteristics.

3. Correlate physical property data with liquid chemical characteristics, i.e., elution chromatography, solvent fractionation, elemental analysis, etc.

Instruments for measuring the viscosity, density, heat capacity, and thermal conductivity of flowing streams of coal liquids will be installed in an existing Coal Liquids Flow Facility (CLFS) shown in Fig. 2.3. The CLFS consists of high pressure liquid and hydrogen supply units, gas preheater, separate coal/oil/gas preheater, a catalytic packed bed reactor, vapor-1iquid separators, and physical properties instruments. Liquid streams can be quenched at test conditions and chemically characterized (i.e., solvent fractionation, elemental analysis, boiling point curve, elution chromatography, etc.) for ultimate correlation.

Pressure and temperature limits for preheaters, reactor, high pressure separator and physical properties equipment are 4500 psig and $1000^{\circ} \mathrm{F}$. The liquid feed pump has 4-liter/hr ultimate capacity, and the hydrogen supply system can deliver up to $270 \mathrm{scfh}$ at $4500 \mathrm{psig}$. The coal/oil/gas preheater test system can carry the combined hydrogen and liquid flow, but the gas preheater is for hydrogen on1y.

The viscometer will be of the falling ring type and has a $0.1-$ $10,000 \mathrm{cp}$ measurement range at conditions up to $4500 \mathrm{psig}$ and $1000^{\circ} \mathrm{F}$. This instrument is shown schematically in Fig. 2.4. Density will be determined by measuring differential pressure across a column of the test fluid of known height (see Fig. 2.5). A well-insulated, heated flow-section will be used for heat capacity measurements (see Flg. 2.6). By measuring the differential temperature rise for known heat input and mass flow rate, the heat capacity can be determined. Thermal conductivity of the fluid samples can be determined by the transient, hot wire method of Grossman and Straumann (see Fig. 2.7). By recording the 


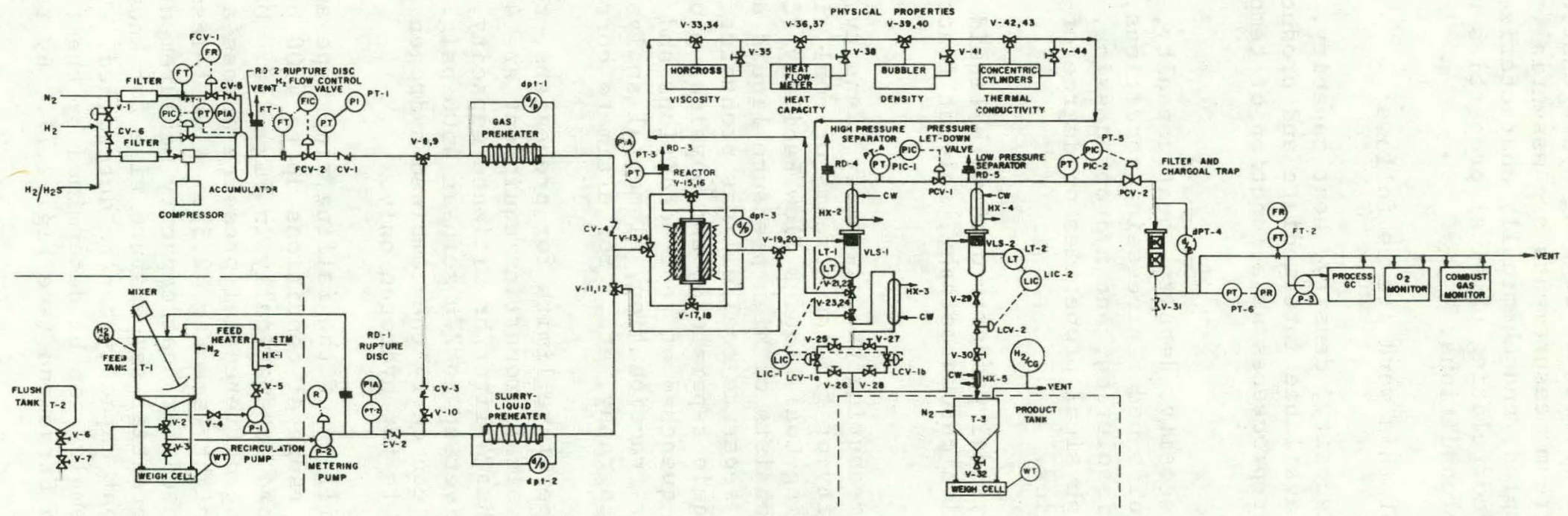

Fig. 2.3. Coa1 liquids flow system. 
ORNL DWG 78-5205

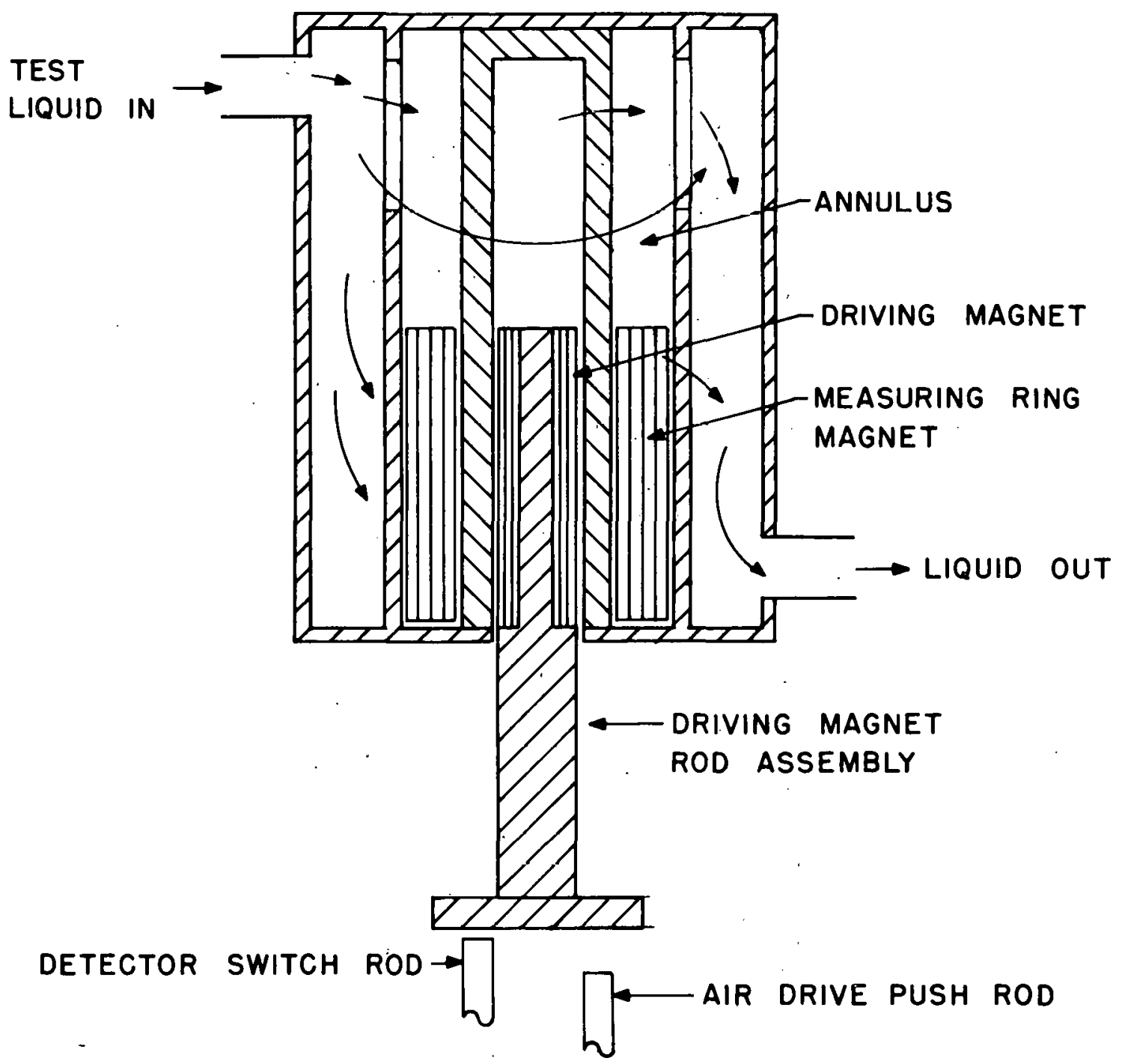

Fig. 2.4. Norcross falling ring viscometer. 
ORNL DWG 78-5197

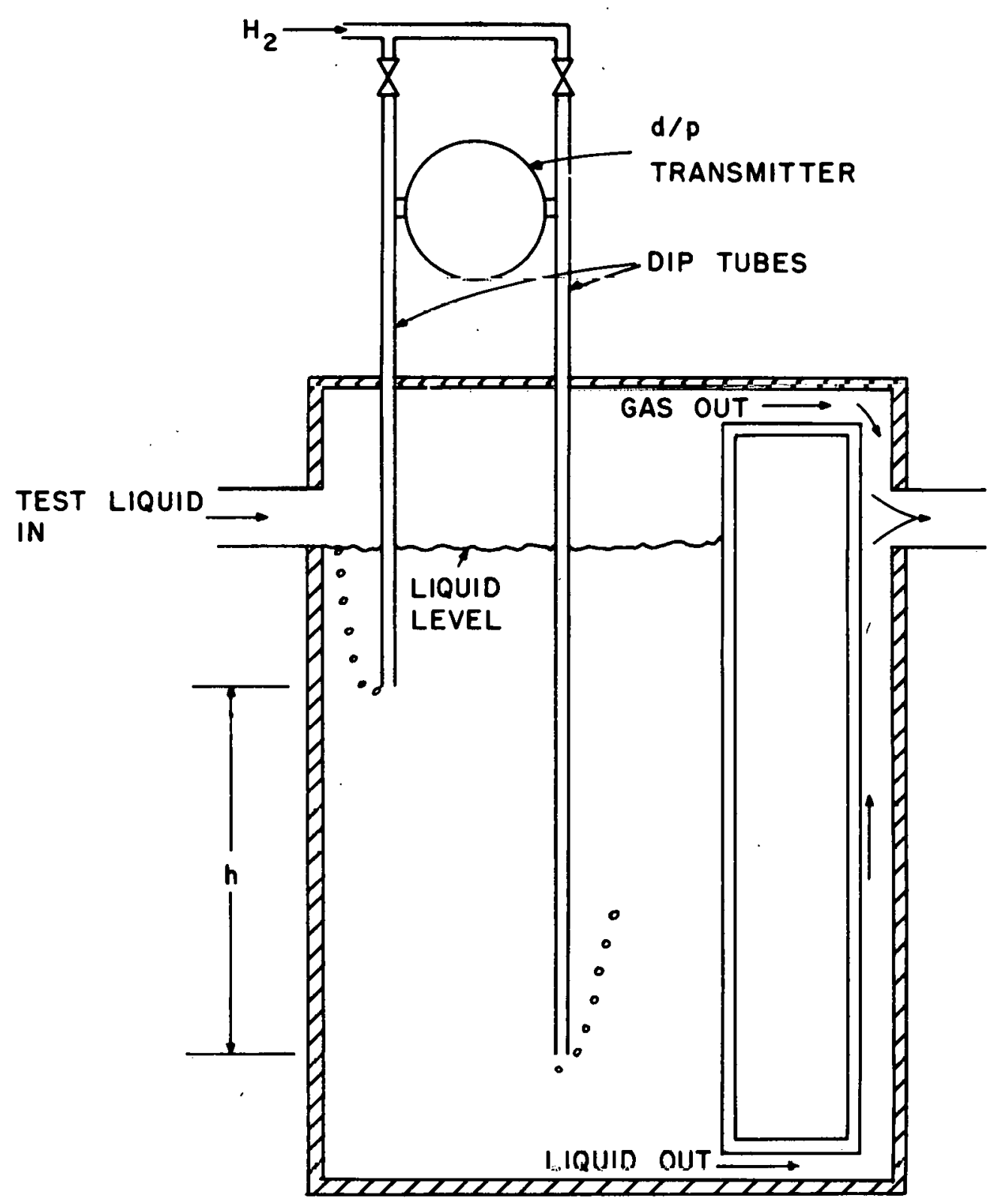

Fig. 2.5. Bubbler densitometer. 
ORNL DWG 78-5204

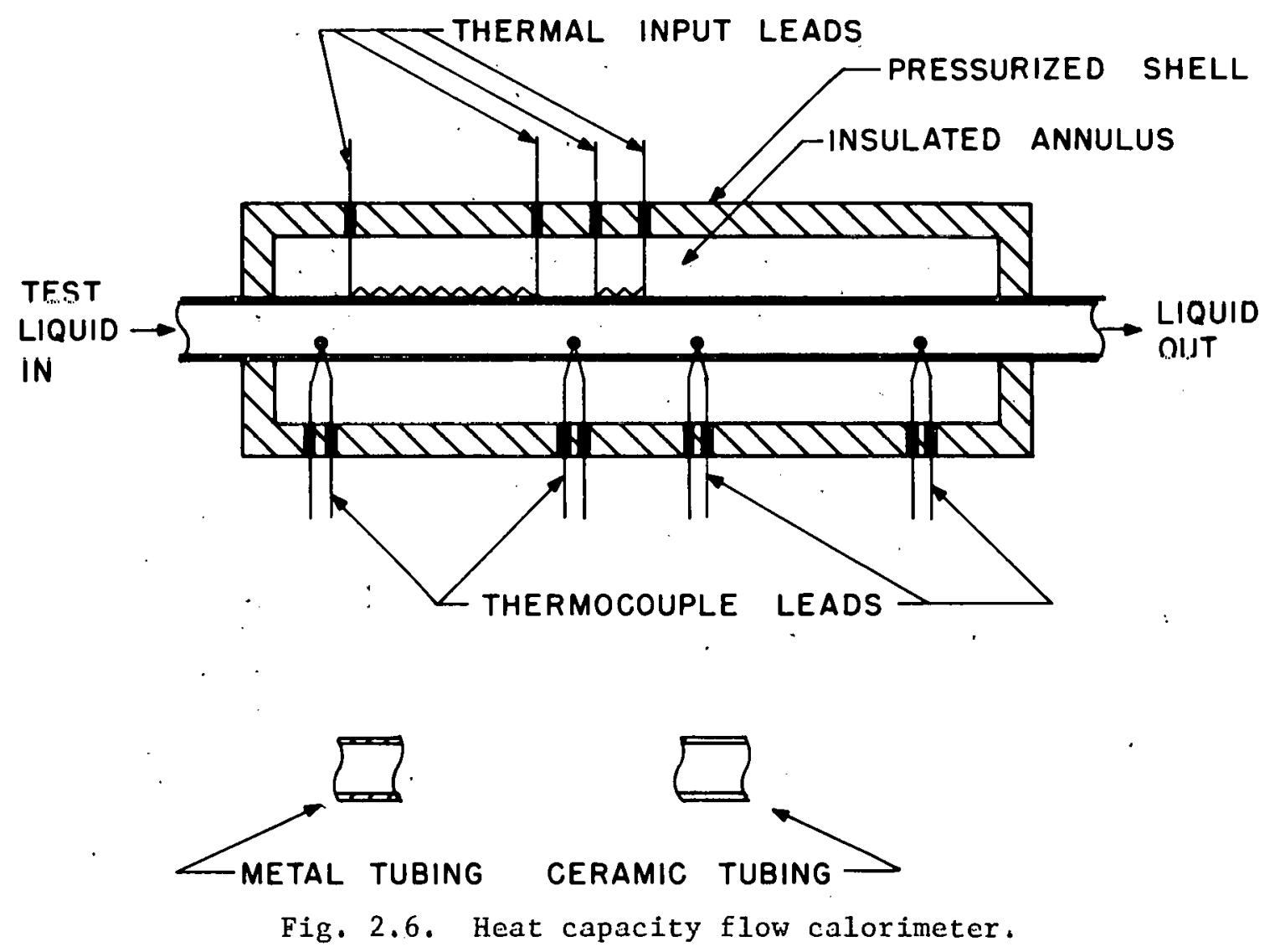


ORNL-DWG $78-5200$

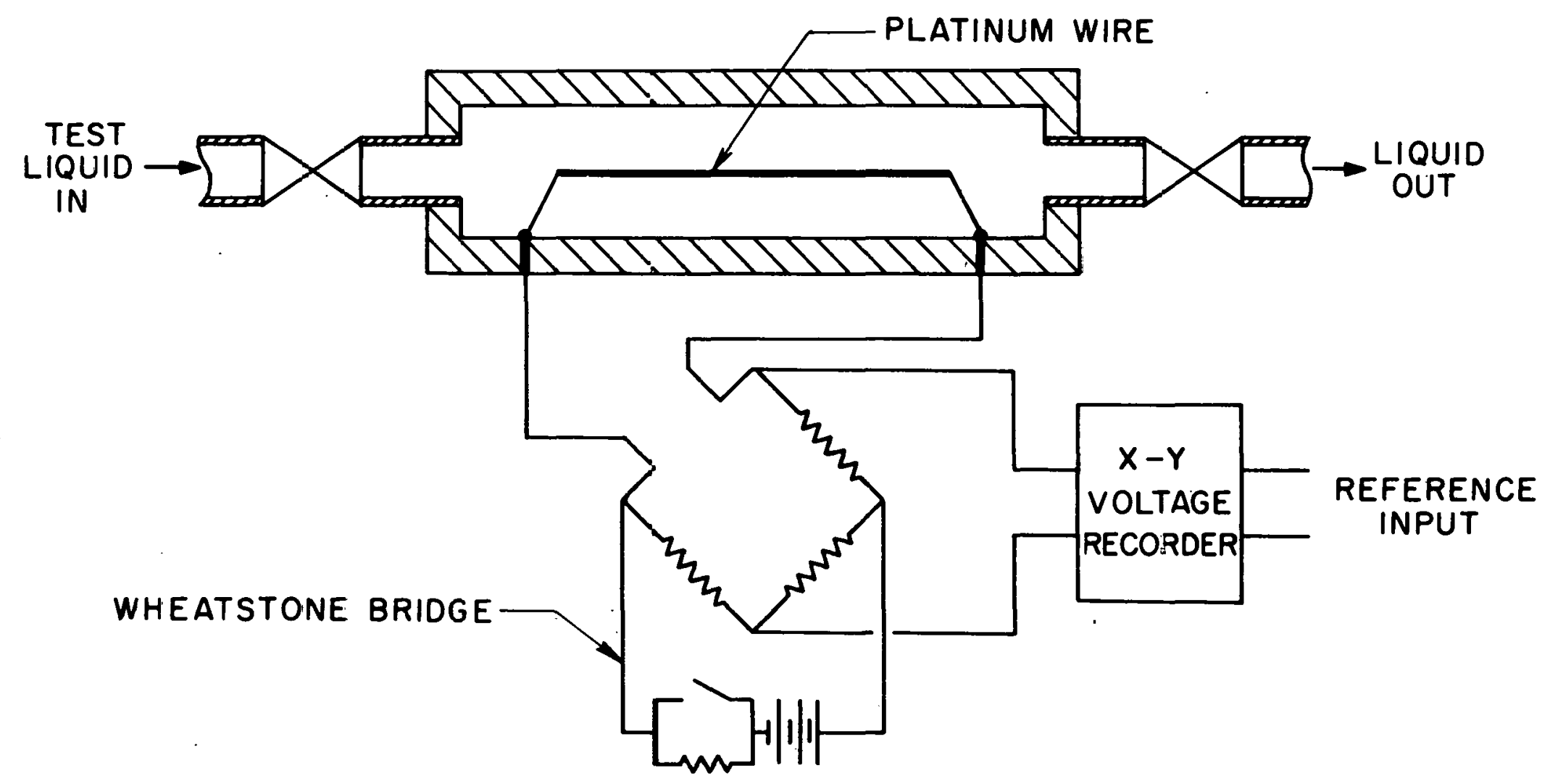

Fig. 2.7. Heated wire thermal conductivity cell. 
resistance of a heated platinum wire relative to a reference wire in a fluid of known conductivity in a wheatstone bridge, thermal conductivity may be determined with good accuracy, without reliance on other fluid properties, in a matter of a few seconds and with very small changes in the fluid temperature.

\subsection{Coal Slurry Preheaters}

H. D. Cochran, Jr.

This is the first report on a new project which was initiated during the month of April. As an introduction to the project this report includes excerpts from the work statement for the project.

In coal liquefaction processes using slurries, such as the SRC process, preheaters are used to heat the slurry or slurry-hydrogen mixture to about $800^{\circ} \mathrm{F}$. During preheating, coal dissolution and chemical reactions occur which change the properties of the slurry. These changes are not well understood and result in difficulties in the design and operation of preheaters. Problems of coking, high pressure drop, poor heat transfer, erosion, etc. have been identified by Fluor Engineers and Constructors, Inc. 1 as areas where consistent data are critically needed for design of a preheater. These problems in preheaters can be solved best by a thorough understanding of the variation in fluid dynamics, chemical characteristics, and fluid properties throughout the preheater leading to improved preheater design and operating practices. This work is aimed specifically toward improved process understanding which may lead to improved equipment concepts and operating procedures. The effort will interact with and utilize results from the project on "Physical Properties of Coal Liquids" at Oak Ridge National Laboratory and will complement a project "Preheater Effects in Coal Liquefaction Processes" at Sandia Laboratories which assesses the effect of preheater parameters on the characteristics of the preheater product. The focus of the present project is on the thermal and rheological characteristics of the fluids in the preheater at preheater conditions.

The objectives of this project are as follows:

1. To have available an operable preheater test system installed in an existing coal liquids flow system capable of determining rheological and heat transfer characteristics of a flowing coal/oil/hydrogen stream at temperatures to $1000^{\circ} \mathrm{F}$ and pressures to $4500 \mathrm{psi}$.

2. To provide measured values and correlation of rheological and heat transfer characteristics of coal/oil/hydrogen streams as a function of operating conditions and design parameters through the preheater test section. 
A bench-scale preheater test unit and associated equipment has been designed and is being constructed in an existing Coal Liquids Flow System (CLFS) at ORNL. The CLFS (shown in Fig. 2.3) consists of high pressure liquid and hydrogen supply units, gas preheater, separate coal/ oil/gas preheater test system, a catalytic packed bed reactor, vapor1iquid separators, and physical properties instruments. Liquid streams can be quenched at test conditions and chemically characterized (i.e., solvent fractionation, elemental analysis, bolling point curve, elution chromatography, etc.) for ultimate correlation.

Pressure and temperature limits for preheaters, reactor, high pressure separator and physical properties equipment are 4500 psig and $1000^{\circ} \mathrm{F}$. The liquid feed pump has 4-liter/hr ultimate capacity, and the hydrogen supply system can deliver up to $270 \mathrm{scfh}$ at $4500 \mathrm{psig.} \mathrm{The} \mathrm{coal/oil/gas}$ preheater test system can carry the combined hydrogen and liquid flow, but the gas preheater is for hydrogen only. The coal/oil/gas preheater test system is designed to permit variable residence time at constant throughput by varying flow path length. Th1s will allow investigation of coal-solvent slurry rheology, heat transfer characteristics, and coking tendency under preheater conditions.

On-1ine physical properties instruments will be available for measuring viscosity, density, heat capacity, and thermal conductivity of the flowing streams.

The coal/oil/gas preheater test section is shown schematically in Fig. 2.8. The test section is well-insulated and is heated by controlled electrical resistance heating. The maximum tube wall temperature is $1000^{\circ} \mathrm{F}$, and the maximum heat flux is $10,000 \mathrm{Btu} / \mathrm{hr} \cdot \mathrm{ft}^{2}$. Provisions are included for measuring the pressure and temperature of the feed and effluent streams and for sampling these streams for chemical characterization. Thermocouples are installed for measuring the axial variation in the preheater wall temperature.

\subsection{New Liquefaction Techniques}

J. W. Larsent and H. D. Cochran, Jr.

This is the first report on a new project which was initiated during the month of April. As an introduction to the project this report includes excerpts from the work statement for the project.

Conventional processes for coal conversion--dissolution, hydrogenation, pyrolysis, extraction--are largely based on trial-and-error improvements to the crude German technology of the 1930's. Significant advances have been made recently in the fundamental understanding of the

*ORNL Chemistry Division and University of Tennessee Department of Chemistry. 
ORNL-DWG 78-5358

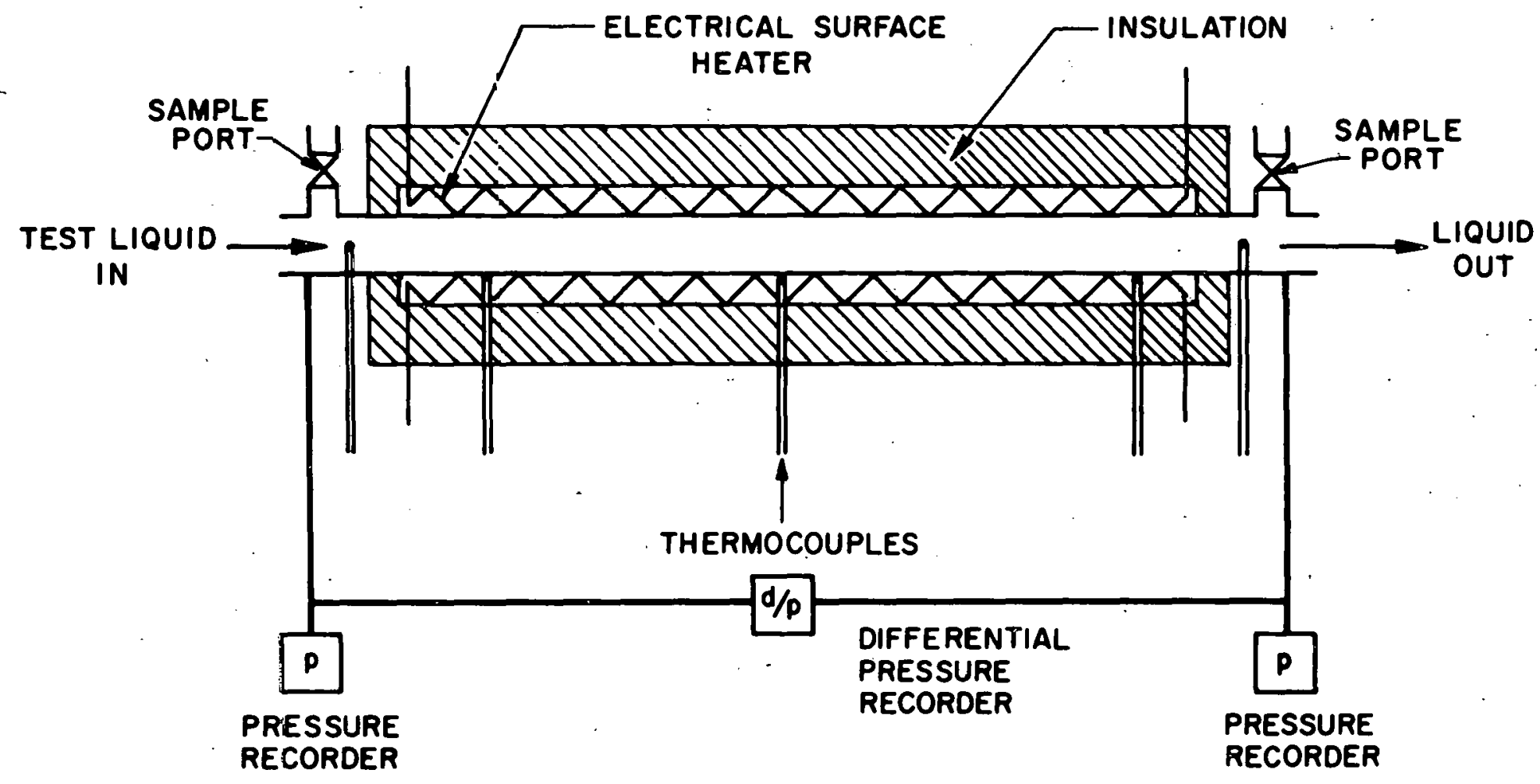

Fig. 2.8. Slurry Preheater Test Section. 
chemical structure of coal through application of advanced chemical methods such as ${ }^{13} \mathrm{C}-\mathrm{NMR}$, gel permeation chromatography, etc. For example, it is now known that coal contains relatively little carbon as polycondensed aromatic clusters, that polynuclear aromatic hydrocarbons are produced by condensation during liquefaction, and that coal contains a significant hydrogen donor capacity itself. There is also evidence that aromatics linked by a single methylene group are rare, while two and three bridges are common. The scope of this program encompasses research studies aimed at better understanding of the chemical processes involved in liquefaction of coal based on recent advanced in knowledge of the structure of coal. This work will seek improved methods of classical conversion technologies as well as entirely new methods for converting coal.

The objective of this work is to exploit recent advances in coal chemistry for possible liquefaction techniques. The rationale for this effort is presented below in the areas of Ionic hydrogenation chemistry and Heredy-Neuworth depolymerization:

1. It has been demonstrated that partial 1iquefaction of coal can be achieved by using $\mathrm{BF}_{3} \cdot \mathrm{H}_{2} \mathrm{O}$ in combination with a hydride donor by an ionic hydrogenation mechanism. There is evidence that the site of attack is at heteroatom-activated structures, and ionic hydrogenation shows promise for selective heteroatom removal during liquefaction.

2. It has been demonstrated that coals can be depolymerized to readily soluble products by heating with phenol in the presence of several acid catalysts. Many liquefaction processes now under development produce a large quantity of phenols. Using these phenols in a Heredy-Neuworth depolymerization should allow the liquefaction of much more coal under mild reaction conditions without the utilization of additional hydrogen.

\subsection{In-Plant Environmental Monitors}

\section{D. Echurcsko}

In-Plant Environmental Monitors, a new fossil energy project whose purpose is the development of a portable survey instrument for monitoring for polynuclear aromatic hydrocarbon ( $\mathrm{PAH}$ ) contamination on work area surfaces in coal research facilities, is being initially reported here. A prototype fluorescence spotter, shown schematically in Fig. 2.9, has been assembled and tested at ORNL. The prototype can detect $10 \mathrm{mg}$ amounts of various PAHs at distances of $0-1000 \mathrm{~cm}$ in work areas with typical ambient illumination, and is sensitive to 10 nanogram amounts of PAHs in darkened work areas. 
ORNL DWG. 77-185IR

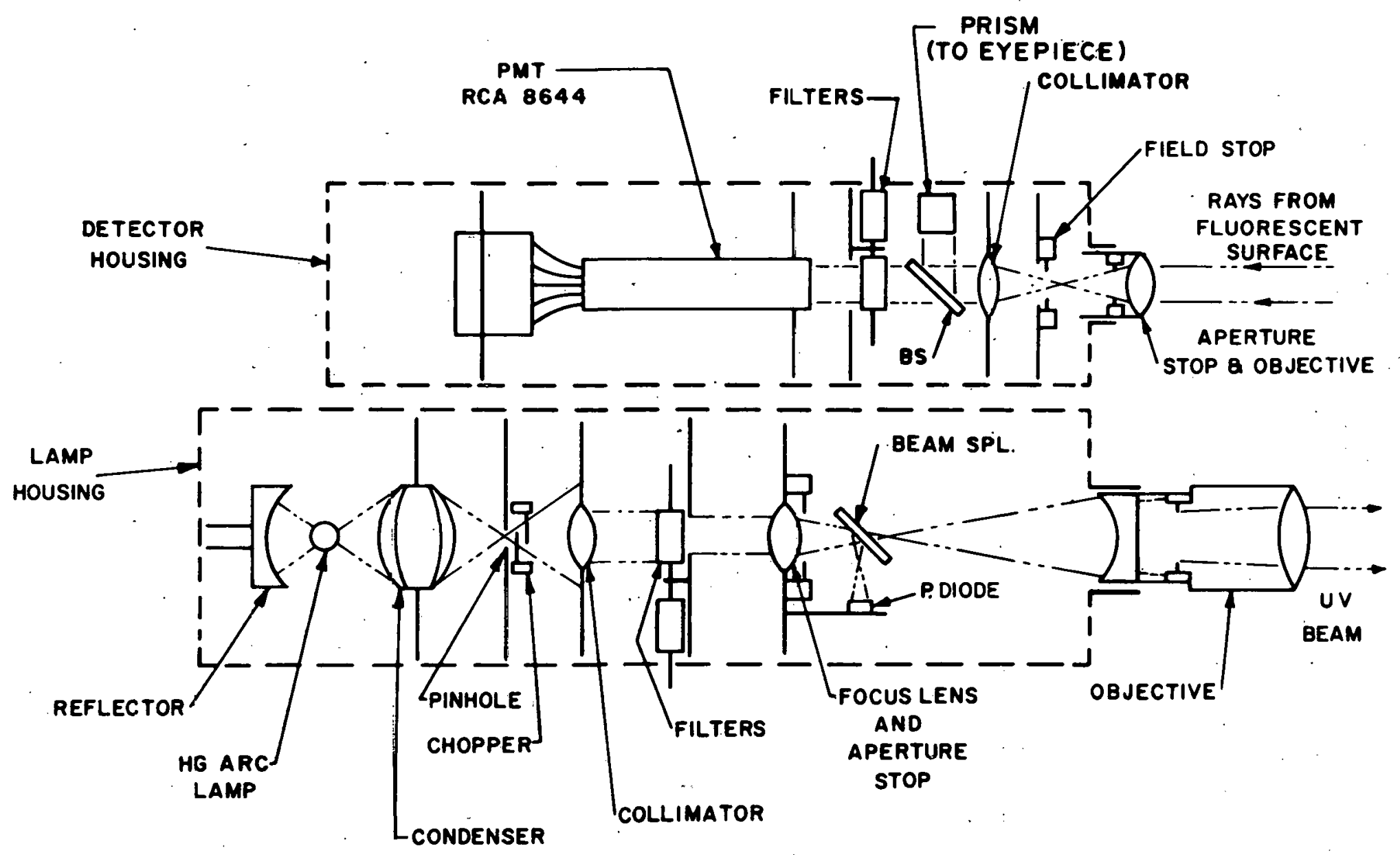

Fig. 2.9. Prototype fluorescence spotter head. 
Design, fabrication, and field testing of a portable version of this device for the purpose of interfacing the initial development to eventual commercial spotter production constitutes this research effort. The principal programmatic objectives are to:

1. Fabricate two portable PAH contamination spotters.

2. Field test spotters in DOE coal research facilities.

3. Evaluate test performance and modify design (if necessary).

4. Compile technical documentation for external distribution.

Current project activities include design of an advanced spotter head which is more compact and more sensitive than the prototype, and development of a prototype portable electronics unit.

\subsection{Experimental Engineering Support of In Situ Gasification Processes}

P. R. Westmoreland, L. S. Dickerson, and C. F. Bertsch

Coal block pyrolysis experimentation continued during April, supporting modeling and field development of in situ (underground) gasification (UCG). Block pyrolysis data are needed for modeling of in situ coal gasification because earlier data described only the pyrolysis of powder samples. By contrast, in situ gasification may react large blocks formed by roof collapse or seam fracturing; possibly. it may react a broad seam cross-section. Internal heat and mass transfer resistances are more important, and product yields can change significantly.

In experiments which began at ORNL in 1975, 6-in.-diam (16-cm) right circular cylinders of lignite, subbituminous coal, and bituminous coal have been pyrolyzed by heating the blocks at $0.3-14 \mathrm{C} / \mathrm{min}$ (surface temperature) from ambient temperature to maximum temperatures of 500$1000^{\circ} \mathrm{C}$. Using an inert (argon) or reducing (hydrogen) purge gas at atmospheric pressure, gas- and vapor-phase reaction products are continuously swept from the reactor. Water, oils, and tars are collected in a water-cooled condenser and by filters, and the remaining noncondensible gases are metered and periodically sampled. In many of the experiments, block temperature profiles have been measured by internal thermocouples. These tests are designed to support modeling of field in situ gasification experiments by Laramie Energy Research Center (LERC), Lawrence Livermore Laboratory (LLL), and Morgantown Energy Research Center (MERC).

Effects of internal heat and mass transfer resistances have been observed in each coal. High water content and the insulating properties of dry coal combined in low-rank coals (1ignite and subbituminous coal), creating a sharp steam front and steep temperature gradients at heating rates of $3 \mathrm{c} / \mathrm{min}$. In subbituminous coal, steam-char gasification 
reactions were observed as steam diffused from the center through the hot char surface. Although water content was low in the bituminous coal, thermal conductivity was low enough to create steep temperature gradients within the block at higher heating rates. These gradients reduced swelling because plasticity of the coal became nonuniform. Because oil and tar yields were decreased with increased external heating rate while water and gas yields increased, steepness of the gradients and mass flow resistance are hypothesized to have caused secondary cracking reactions of the oils and tars.

\subsubsection{Recent experiments and data}

Experiment BP2-47 continued the series of lignite experiments initiated in March. Experimental conditions are summarized in Table 2.3, and gas evolution data for $\mathrm{BP} 2-47$ are listed in Table 2.4. In each experiment a fragile, crumbly char block was produced, and its fragments could easily be reduced to powder. The char block was shrunken from the size of the coal block, and internally it was of uniform consistency. When the block was exposed to air, some pyrophoric behavior was observed. Each of these characteristics was also present in earlier chars from block pyrolysis experiments on subbituminous coal.

A data acquisition system had been developed and tested at the end of the month to record temperature and flowrates. Using an available PDP 11/40 minicomputer, software and analog-to-digital conversion equipment were prepared. Effluent flowrate is measured from elapsed timebetween the electrical pulses transmitted at each revolution of a wet test meter. From internal block thermocouples with $0^{\circ} \mathrm{C}$ reference junctions, millivolt signals are read directly. All data are stored on magnetic tape. Data precision will be improved by use of this system, and evaluation of derived data (such as temperature profiles) will be simplified.

\subsubsection{Bituminous coal: $\mathrm{C}_{2}$ 's as tracer compounds for pyrolysis cracking}

Analysis of ethane $\left(\mathrm{C}_{2} \mathrm{H}_{6}\right)$ and ethylene $\left(\mathrm{C}_{2} \mathrm{H}_{4}\right)$ evolution from block pyrolysis of bituminous coal suggests that (1) ethane evolution may be a tracer for coal pyrolysis reactions and that (2) ethylene evolution may be a tracer for secondary cracking reactions.

Overall yields of $\mathrm{C}_{2}$ 's from bituminous coal were reported earlier ${ }^{2}$. These preliminary data have been refined, and using mass spectrometry data for gas in experiments BP2-23 through BP2-39, $\mathrm{C}_{2} \mathrm{H}_{6} / \mathrm{C}_{2} \mathrm{H}_{4}$ yields have been resolved. Experimental conditions and gas yields are listed in Table 2.5.

From the graph of $\mathrm{C}_{2}$ yields vs. maximum pyrolysis temperature (Fig. $2.10)$, it appears that heating rate exerts the strongest effect on $\mathrm{C}_{2}$ evoiution with some effect of $\mathrm{H}_{2}$ at $3 \mathrm{C} / \mathrm{min}$. As discussed above, higher 
Table 2.3. Summary of exferimental conditions for pyrolysis experiments using a hydrogen purge gas and lignite block.

\begin{tabular}{|c|c|c|c|c|c|c|c|}
\hline \multirow{3}{*}{$\begin{array}{c}\text { Run } \\
\text { number }\end{array}$} & \multirow{3}{*}{$\begin{array}{l}\text { Date of } \\
\text { run }\end{array}$} & \multirow{3}{*}{$\begin{array}{l}\text { Heating } \\
\text { rate } \\
\left(\mathrm{C}^{\circ} / \mathrm{min}\right)\end{array}$} & \multirow{3}{*}{$\begin{array}{c}\text { Maximum } \\
\text { temferature } \\
\left({ }^{\circ} \mathrm{C}\right)\end{array}$} & \multirow{3}{*}{$\begin{array}{c}\mathrm{H}_{2} \text { cover } \\
\text { gas flow rate } \\
\text { (Std. liter/min) }\end{array}$} & \multicolumn{3}{|c|}{ Coal block ${ }^{a}$} \\
\hline & & & & & Dimens & ons $(\mathrm{cm})$ & Weight \\
\hline & & & & & Eeight & Diameter & (kg) \\
\hline BP 2-46 & $3 / 31 / 78$ & 3 & 800 & 2.87 & 15.9 & 13.5 & 3.609 \\
\hline BP 2-47 & $2 / 12 / 78$ & 3 & 1000 & 2.90 & 17.5 & 15.1 & 3.921 \\
\hline
\end{tabular}

axperinents have used lignite from the Wilcox formation, Rockdale, Texas. 
Table 2.4. Summary of preliminary gas evolution data from experiment BP2-47 (block pyrclysis of lignite to $1000^{\circ} \mathrm{C}$ at $3 \mathrm{C} / \mathrm{min}, \mathrm{H}_{2}$ purge gas).

\begin{tabular}{|c|c|c|c|c|c|c|c|c|}
\hline & Total & $\mathrm{H}_{2}$ & $\mathrm{CH}_{4}$ & $\mathrm{C}_{2}{ }^{\prime} \mathrm{s}$ & $c_{3}^{\prime} s$ & $\mathrm{Co}$. & $\mathrm{CO}_{2}$ & $\mathrm{H}_{2} \mathrm{~S}$ \\
\hline \multicolumn{9}{|l|}{ Gas evoluticn } \\
\hline Volumetric (std. 1iters) & 1286.0 & 591.5 & 209.3 & 12.96 & 2.48 & 308.4 & 156.8 & 4.35 \\
\hline Mass $(g)$ & 924.9 & 53.22 & 149.8 & 17.11 & 4.80 & 385.4 & 307.9 & 6.62 \\
\hline $\begin{array}{l}\text { Average composition of evolved gas } \\
\quad(\text { Vol } \%)\end{array}$ & -- & 46.00 & 16.28 & 1.008 & 0.193 & 23.98 & 12.19 & 0.338 \\
\hline \multicolumn{9}{|l|}{ Elemental ccmposition (g) } \\
\hline $\begin{array}{l}\text { Carbon } \\
\text { Hydrogen } \\
\text { Sulfur } \\
\text { Oxygen }\end{array}$ & $\begin{array}{c}379.3 \\
95.3 \\
6.23 \\
444.0\end{array}$ & & & & & & & \\
\hline $\begin{aligned} \text { Gas higher heating value } & (M J) \\
& \text { (Btu) } \\
& (\text { Btuiscf) }\end{aligned}$ & $\begin{array}{l}22.60 \\
21425 \\
438.0\end{array}$ & & $\because$ & & & & & \\
\hline
\end{tabular}


Table 2.5. Comparison of $\mathrm{C}_{2} \mathrm{H}_{4}$ and $\mathrm{C}_{2} \mathrm{H}_{6}$ ylelds from block pyrolysis of Pittsburgh seam bituminous coal.

\begin{tabular}{|c|c|c|c|c|c|c|}
\hline Experiment & $\begin{array}{c}\text { Purge } \\
\text { gas }\end{array}$ & $\begin{array}{c}\text { Reactor heating } \\
\text { rate } \\
\left(\mathrm{C}^{\circ} / \mathrm{min}\right)\end{array}$ & $\begin{array}{l}\text { Maximum } \\
\text { temperature } \\
\left({ }^{\circ} \mathrm{C}\right)\end{array}$ & $\frac{\text { istd }}{\mathrm{C}_{2} \mathrm{H}}$ & $\begin{array}{r}\mathrm{C}_{2} \text { yield } \\
\ell / \mathrm{kg} \text { maf } \\
\frac{\mathrm{C}_{2} \mathrm{H}_{6}}{}\end{array}$ & $\frac{s}{\text { cóal) }}$ \\
\hline BP $2-28$ & Ar & 0.3 & 600 & 0.36 & 7.75 & 8.11 \\
\hline BP 2-31 & Ar & 0.3 & 800 & 0.19 & 7.72 & 7.90 \\
\hline BP $2-23$ & Ar & 0.3 & 1000 & 0.43 & 9.26 & 9.69 \\
\hline BP 2-26 & Ar & 0.3 & 1000 & 0.17 & 7.41 & 7.58 \\
\hline BP $2-30$ & Ar & 0.3 & 1000 & 0.22 & 10.09 & 10.32 \\
\hline BP $2-27$ & Ar & 3 & 600 & 4.44 & 10.48 & 14.92 \\
\hline BP $2-25$ & Ar & 3 & 800 & 8.85 & 6.70 & 15.55 \\
\hline BP $2-24$ & Ar & 3 & 1000 & 9.25 & 6.83 & 16.08 \\
\hline BP 2-32 & Ar & 3 & 1000 & 11.66 & $\because 7.52$ & 19.18 \\
\hline BP $2-41$ & $\mathrm{H}_{2}$ & 0.3 & 600 & -- & -- & 9.93 \\
\hline BP 2-45 & $\mathrm{H}_{2}$ & 0.3 & 800 & -- & -- & 7.35 \\
\hline BP 2-42 & $\mathrm{H}_{2}$ & 0.3 & 905 & -- & - & 9.94 \\
\hline BP 2-39 & $\mathrm{H}_{2}$ & 0.3 & 925 & 0.22 & 9.99 & 10.21 \\
\hline BP 2-43 & $\mathrm{H}_{2}$ & 0.3 & 1032 & -- & -- & 12.43 \\
\hline BP 2-33 & $\mathrm{H}_{2}$ & 3 & 640 & 8.34 & 11.63 & 19.97 \\
\hline BP 2-35 & $\mathrm{H}_{2}$ & 3 & 800 & 13.06 & 7.59 & 20.65 \\
\hline BP 2-37 & $\mathrm{H}_{2}$ & 3 & 880 & 9.44 & 7.97 & 17.41 \\
\hline BP 2-34 & $\mathrm{H}_{2}$ & 3 & 1000 & 7.69 & 9.28 & 16.97 \\
\hline BP 2-38 & $\mathrm{H}_{2}$ & 14 & 890 & 15.15 & 7.20 & 22.35 \\
\hline
\end{tabular}




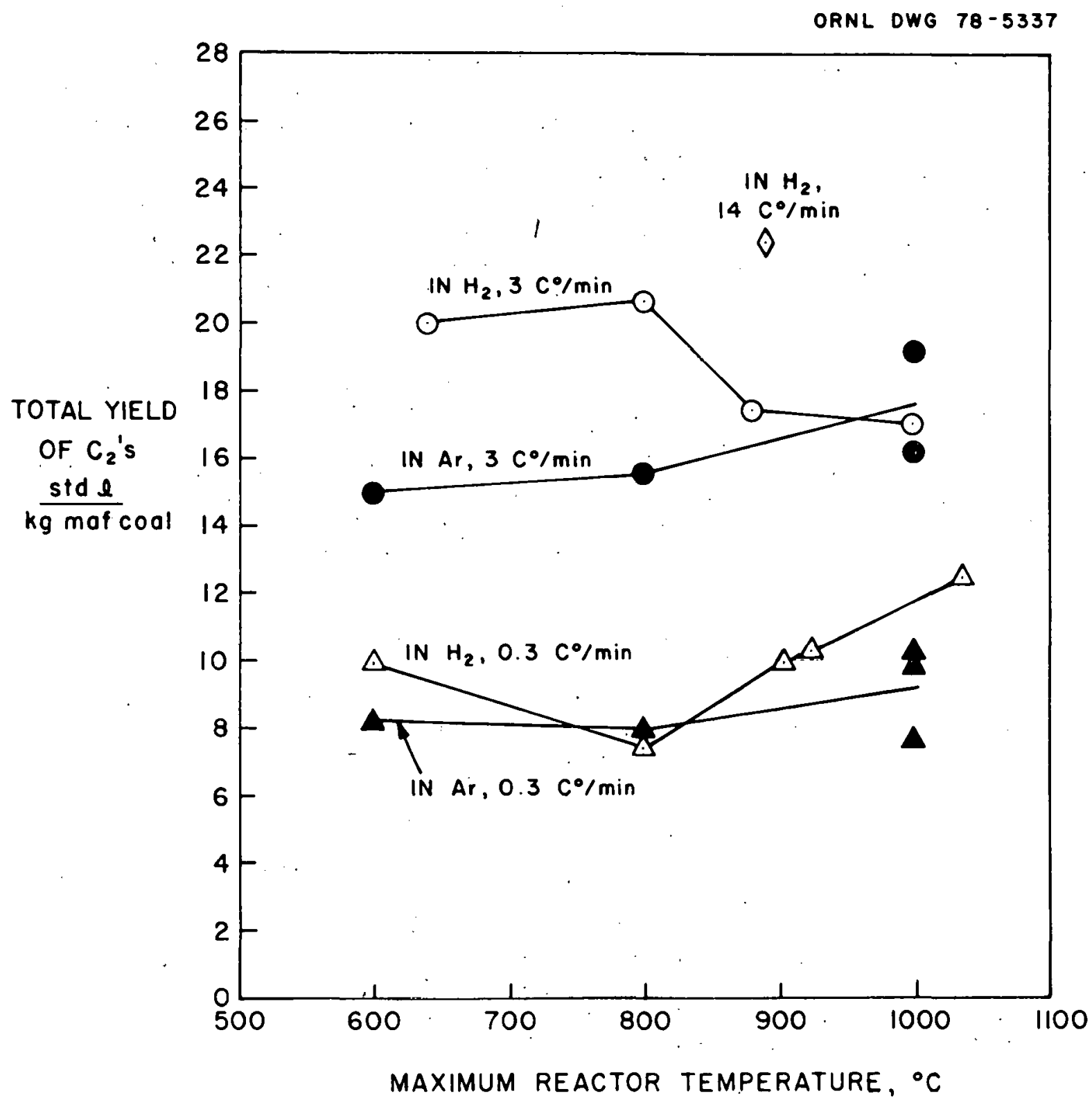

Fig. 2.10. Evolution of $\mathrm{C}_{2}$ hydrocarbons from block pyrolysis of bituminouo coal. 
heating rates are also associated with steeper temperature gradients within the block. However, analysis of mechanisms for $\mathrm{C}_{2}$ evolution depends on separate evaluation of $\mathrm{C}_{2} \mathrm{H}_{6}$ and $\mathrm{C}_{2} \mathrm{H}_{4}$ yields.

Ethane yield proved to be nearly constant at maximum pyrolysis temperatures above $600^{\circ} \mathrm{C}$, independent of heating rate and purge gas composition. For 14 points, average ethane yield was $8.58 \mathrm{std} \mathrm{l} / \mathrm{kg}$ maf coal, with a sample standard deviation of 1.52. Apparently ethane evolution was almost solely from coal pyrolysis reactions occurring below $600^{\circ} \mathrm{C}$. Little cracking to ethylene, production from hydrogenation of ethylene, or production from secondary cracking of liquids seems to have occurred. Because of this behavior, ethane could be a useful tracer during forward gasification to indicate the amount of coal pyrolȳzed in sicu.

Variation in ethylene yield accounts for the variation in overall $\mathrm{C}_{2}$ yield (Fig. 2.11). Increased ethylene yield at higher heating rates (steeper temperature gradients) is further evidence that ofls and tars may be cracked as they diffuse outwards through the hot outer surface of a char block. Although it is more reactive than ethane and thus more susceptible to side reactions, ethylene yield may be a useful tracer for the amount of secondary cracking occurring in situ.

\subsubsection{Thermal conductivity in subbituminous coal blocks}

Temperature data from block pyrolysis have been used to estimate thermal conductivity of dried, unpyrolyzed subbituminous coal. These temperature, measured in experiment BP1-4 as functions of radius and time, were applied to a simple heat and mass transfer model of the cylinder.

A cross-section at mid-height of the right circular cylinder was chosen to be modeled. Since block helght was greater than block diameter, axial variations at the mid-plane were assumed negligible, so all heat and mass transfer would be radially directed. Within the dried, unpyrolyzed region, only steam is flowing outward. Heat transfer processes present would be superheating of the flowing steam, conductive heat transfer through the coal, and heat accumulation in the coal.

Models of these processes may be applied to an annular balance element. Steam contacts the coal structure intimately as it diffuses outward, so heat transfer to the steam should be rapid. If so; this heat transfer step may be modeled as an enthalpy change. The resulting equation for thermal conductivity, $k$, is:

$$
k=\frac{2 \pi \cdot \rho \operatorname{coal} \cdot\left(C_{p}\right) \operatorname{coal} \cdot r \cdot \frac{\partial T}{\partial t}+\left(\frac{\dot{m} \text { steam }}{H}\right) \cdot\left(C_{p}\right) \text { stèam } \cdot \frac{\partial T}{\partial r}}{2 \pi \cdot \frac{\partial}{\partial r}\left(r \frac{\partial T}{\partial r}\right)}
$$




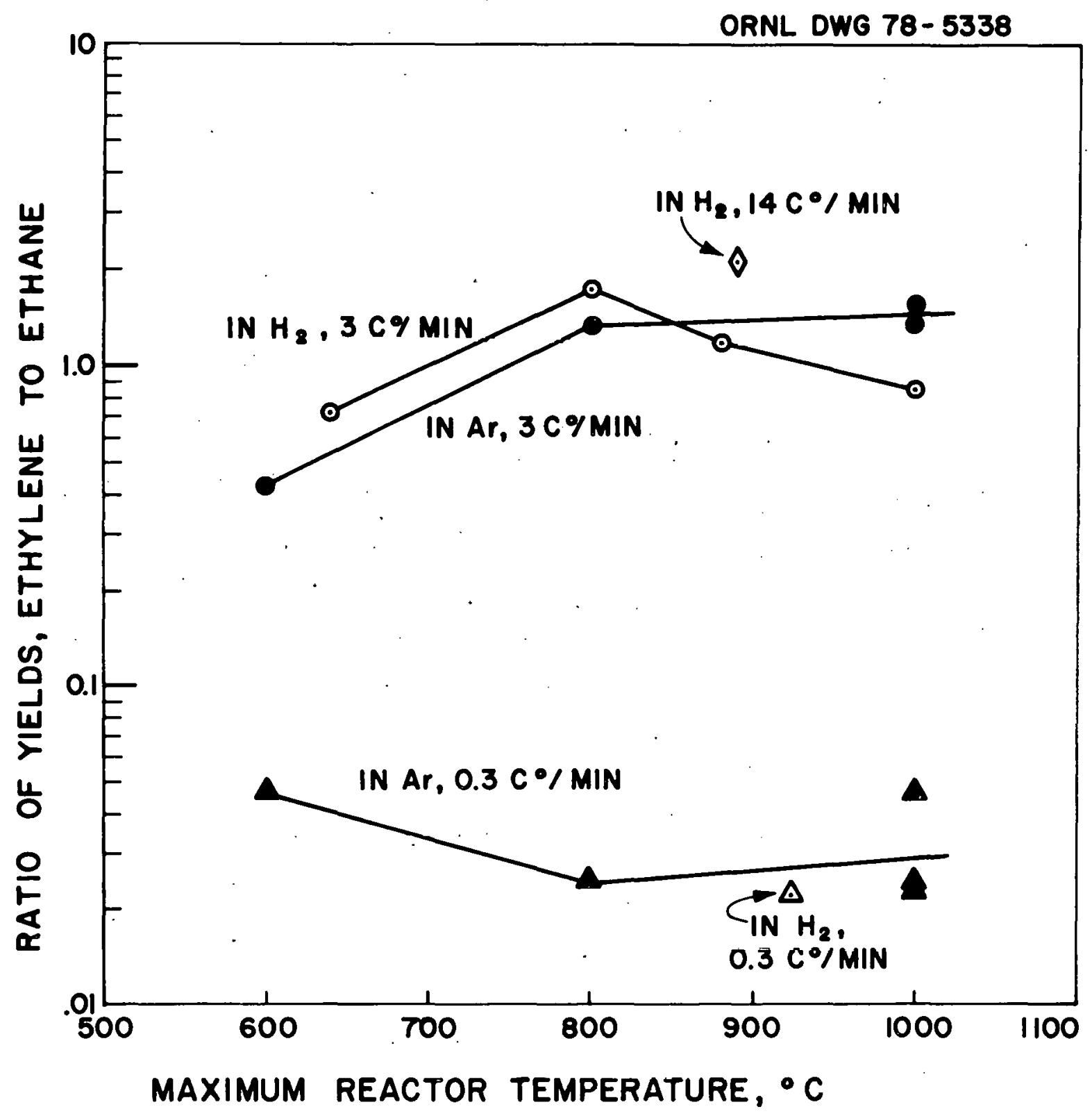

Fig. 2.11. Relative yields of ethylene/ethane from block pyrolysis of bituminous coal. 
where: $k=$ thermal conductivity, $\operatorname{cal} / \mathrm{sec} \cdot \mathrm{cm} \cdot \mathrm{C}^{\circ}, \mathrm{W} / \mathrm{m} \cdot \mathrm{K}$, or $\mathrm{Btu} / \mathrm{hr} \cdot \mathrm{F}^{\circ} \cdot \mathrm{ft}$,

$$
\begin{aligned}
& \rho \text { coal = coal density }(\mathrm{dry}), 1.03 \mathrm{~g} / \mathrm{cm}^{3}, \\
& (\mathrm{Cp}) \text { coal = specific heat of dry coal, } 0.26 \mathrm{cal} / \mathrm{g} \cdot \mathrm{C}^{\circ}, \\
& \mathrm{r}=\text { cylinder radius, } \mathrm{cm}, \\
& \mathrm{T}=\text { temperature, }{ }^{\circ} \mathrm{C}, \\
& \mathrm{t}=\text { time, sec, } \\
& \text { th }{ }_{\text {steam }} / \mathrm{H} \equiv \text { mass flow rate of steam per unit helght of cylinder, } \\
& \text { g/sec.cm, } \\
& \text { (Cp) steam }=\text { specific heat of steam, cal } / \mathrm{g} \cdot \mathrm{C}^{\circ} .
\end{aligned}
$$

Using this equation, thermal conductivity was calculated from experimental data. Values for the gradients, $\partial T / \partial r$ and $\partial T / \partial t$, were measured from Figs. 2.12 and 2.13 at a given time and at four radial positions lying in the $150-400^{\circ} \mathrm{C}$ region. Since $\partial \mathrm{T} / \partial \mathrm{r}$ was nearly constant within that region, the partial derivative in the denominator was reduced to $\partial \mathrm{T} / \partial \mathrm{r}$ for these preliminary analyses. The steam rate $\dot{\mathrm{m}}_{\mathrm{steam}} / \mathrm{H}$ was derived from the rate of movement, $\mathrm{dr}^{\prime} / \mathrm{d} t$, of the steam front (determined graphically from Fig. 2.14) and from a model of steam front movement as purely thermal drying:

$$
\frac{\dot{\mathrm{m}}_{\text {steam }}}{\mathrm{H}}=2 \mathrm{r}^{\prime} \cdot \frac{\mathrm{d} \mathrm{r}^{\prime}}{\mathrm{dt}} \cdot \rho \operatorname{coal} \text {, wet } \cdot \frac{\mathrm{M}}{100}
$$

where: $\mathbf{r}^{\prime}=$ radial position of steam front, $\mathrm{cm}$,

$$
\begin{aligned}
& \rho \text { coal, wet }=\text { density of wet coal, } 1.293 \mathrm{~g} / \mathrm{cm}^{3} \text {, } \\
& M=\% \mathrm{H}_{2} 0 \text { in wet coal }=30.0 \%
\end{aligned}
$$

Calculated thermal conductivities are presented in Table 2.6. Values in the range $2.3-4.8 \mathrm{Btu} / \mathrm{hr} \cdot \mathrm{ft}^{2} \cdot\left({ }^{\circ} \mathrm{F} / \mathrm{in}.\right)$ are reasonable. For comparison, $\mathrm{k}$ for 304 stainless steel is 113; for cinder concrete, 2-4; and for styrofoam, 0.20. However, the apparent increase of $k$ is unexpected. At any given time, the values seem consistent, but as time progresses and the steam front nears the block center, $k$ seems to increase. Whether this change results from physical changes or from the model analysis, modeling of in situ gasification can benefit from continued analysis and evaluation ot this type. 


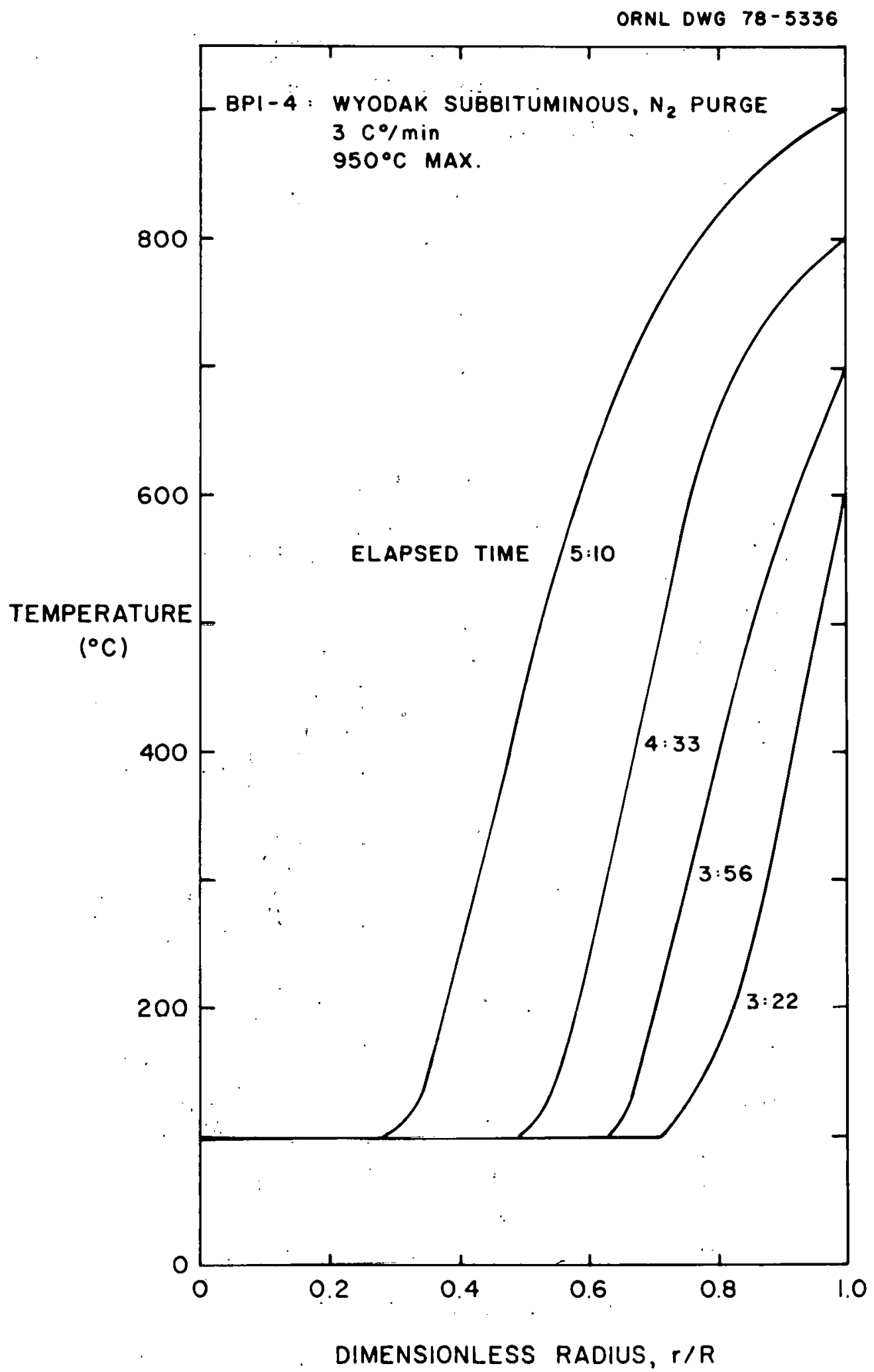

Fig. 2.12. Interior temperature profiles in a subbituminous coal block. Each profile based on 26 data points; block diameter $R=3$ in. 


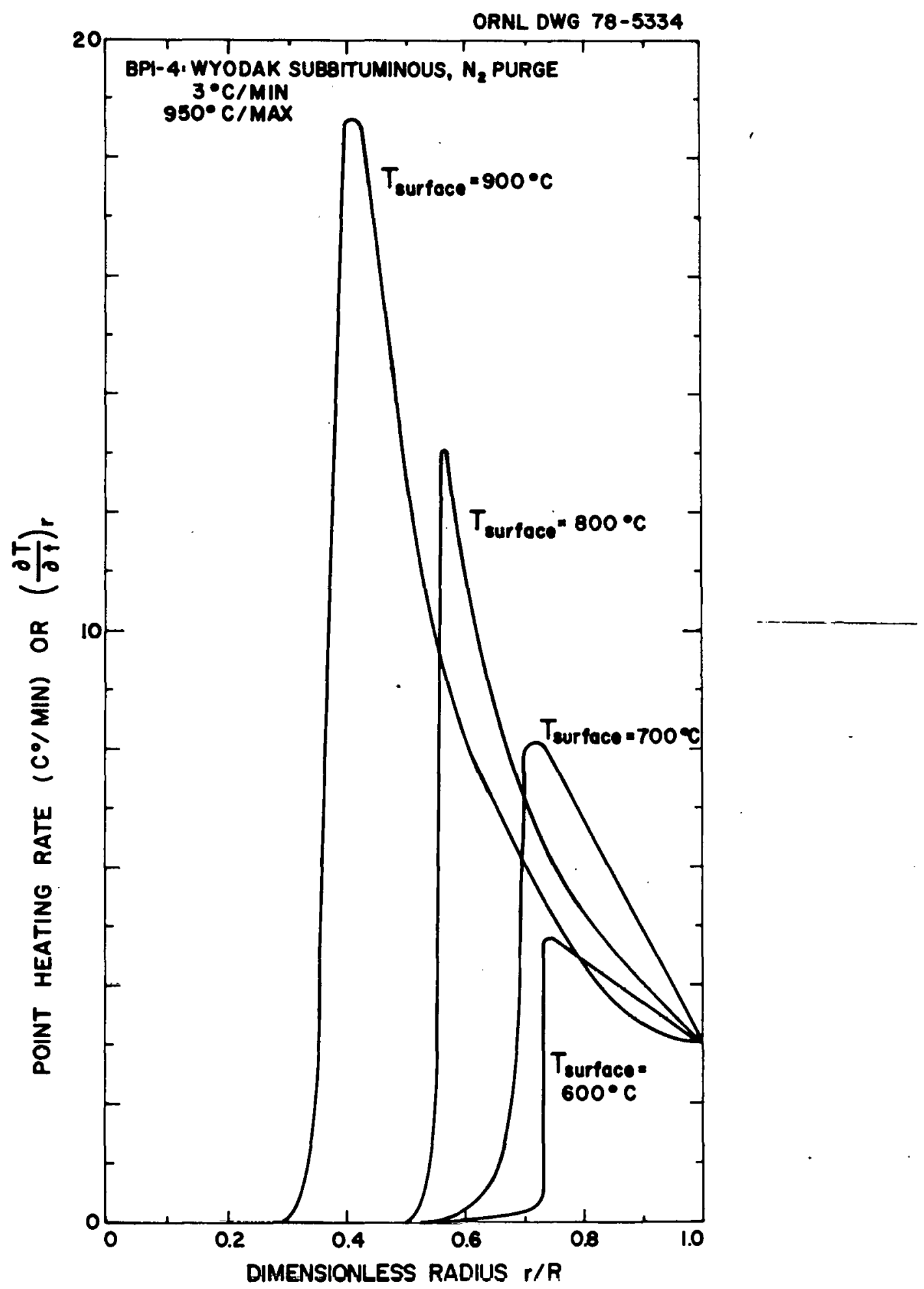

Fig. 2.13. Point heating rates within a subbituminous coal block. Each curve based on 26 data points; block radius $R=3$ in. 


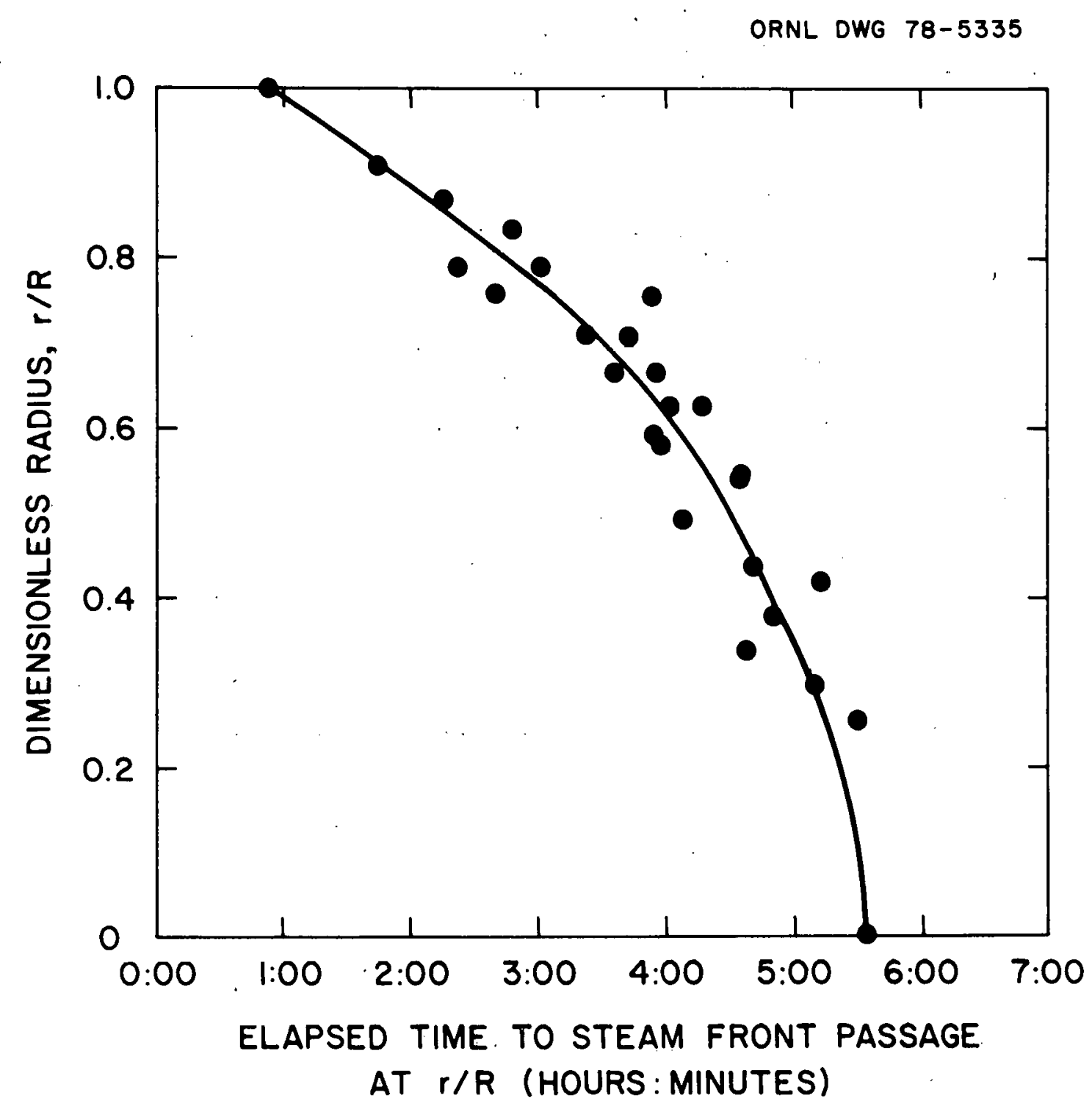

Fig. 2.14. Radial movement of steam front in experiment BP1-4. Block radius $R=3$ in. 


\section{6 .4 Work forecast}

Lignite experiments will continue during May along with evaluation of subbituminous and bituminous coal data. Condensibles from bituminous coal pyrolysis have been submitted for chemical and physical analysis. Using computer data acquisition of temperature data, analysis of 1ignite data by the methods outlined in Section 2.6 .3 will begin.

Table 2.6. Calculated thermal conductivities for dry Wyodak subbituminous coal.

\begin{tabular}{cccc}
\hline $\begin{array}{c}\text { Elapsed } \\
\text { time } \\
(\mathrm{hr}: \mathrm{min})\end{array}$ & $\begin{array}{c}\text { Surface } \\
\text { temperature } \\
\left({ }^{\circ} \mathrm{C}\right)\end{array}$ & $\begin{array}{c}\text { Thermal } \\
\text { conductivity } \\
\mathrm{k}\left[\mathrm{Btu} / \mathrm{hr} \cdot \mathrm{ft}^{2} \cdot\left({ }^{\circ} \mathrm{F} / \mathrm{in} .\right)\right]\end{array}$ & $\begin{array}{c}\text { Range of k, } \\
\text { calculat1ons }\end{array}$ \\
\hline $3: 22$ & 600 & 2.3 & $2.26-2.29$ \\
$3: 56$ & 700 & 3.5 & $3.36-3.50$ \\
$4: 33$ & 800 & 3.7 & $3.34-4.12$ \\
$5: 10$ & 900 & 4.8 & $4.64-4.91^{\mathrm{a}}$ \\
\hline $\mathrm{a}_{\text {Three calculations }}$ & &
\end{tabular}

\subsection{References for Section 2}

1. "Coal Liquefaction Design Practices Manual," PB-257 541 (July 1976).

2. Fossil Energy Program Progress Report for March, 1978, ORNL/TM-6385 (May 1978). 


\section{MATERIALS ENGINEERING}

\section{R. T. King}

The materials engineering and associated technology reported here are in support of activities directed by the Materials Branch of Plant Initial Operation Materials and Components Office of the Division of Coal Conversion, Fossil Energy. Other related work not funded directly by this division of $\mathrm{DOE} / \mathrm{FE}$ is included also.

\subsection{Pressure Vessel and Piping Materials}

R. 0. Williams, W. J. Stelzman and D. A. Canonico

\subsubsection{Pressure Vessel and Piping Materials (W. J. Stelzman and D. A. Canonico)}

Charpy and tensile specimens are being machined from bars of 2 1/4 Cr-1 Mo steel that have received a simulated "Data Trak" quench of $0.3 \mathrm{~K}(0.6 \mathrm{R}) / \mathrm{s}$ from $972^{\circ} \mathrm{C}\left(1700^{\circ} \mathrm{F}\right)$ or $1038^{\circ} \mathrm{F}\left(1900^{\circ} \mathrm{F}\right)$ followed by tempering $1 \mathrm{hr}$ at $704^{\circ} \mathrm{C}\left(1300^{\circ} \mathrm{F}\right)$, or tempering followed by stress relieving $40 \mathrm{hr}$ at $677^{\circ} \mathrm{C}\left(1250^{\circ} \mathrm{F}\right)$. The specimens will be tested as soon as they are received.

Additional $21 / 4 \mathrm{Cr}-1$ Mo steel specimen bars are being prepared which will receive the nominal quench rates of $0.3 \mathrm{~K} / \mathrm{s}$ (slow cool) and $2.5 \mathrm{~K}(4.5 \mathrm{R}) / \mathrm{s}$ (fast cool) from $972^{\circ} \mathrm{F}$. Part of these bars will be used to investigate the effect of tempering followed by stress relieving for $120 \mathrm{hrs}$ and the effect of aging for $1000 \mathrm{hrs}$ after tempering and stress relieving for $40 \mathrm{hrs}$. The remainder of the bars will be used to initiate a static fracture toughness ( $\mathrm{K}_{\mathrm{Icd}}$ ) study using precracked Charpy specimens. The static fracture toughness of bars quenched from $972^{\circ} \mathrm{C}$ at the fast and slow cooling rates will be determined for three additional heat treatments: quenched and tempered; quenched, tempered and stress relieved $40 \mathrm{hrs;}$ and quenched, tempered, stress relieved and aged for 1000 hrs. The same sequence will be followed with bars quenched from $1038^{\circ} \mathrm{C}$ at the fast and slow cooling rates with the exception that the aging will not be included.

\subsubsection{Hydrogen Attack (R. 0. Williams)}

The increased resistance of alloy steels to hydrogen attack has been estimated based upon the calculated activity of carbon. The results are in satisfactory agreement with the Nelson curves for these steels considering that important kinetic effects remain to be resolved. 


\subsection{Inspection Techniques for Wear- and Process-Resistant Coatings}

R. W. McClung and G. W. Scott

\subsubsection{Review and Evaluation (G. W. Scott)}

Two topical reports, ORNL/TM-6176 and ORNL/TM-6210, have been reproduced and mailed to designated recipients.

\subsubsection{Specimens and Standard Fabrication (G. W. Scott and D. P. Edmonds)}

Three new blanks for CoCrAlY disc specimens have been machined. The No. 2 dlsc, with a 1/16-in. backing for the sprayed layer, was coated with CoCrA1Y and machined to smooth the oversprayed rim and remove the metal backing. The coating was found separated from the backing in the center part of the coated area. This effect is thought to result from differences in the coefficients of thermal expansion and cooling rates of the substrate and coating. We are looking at ways to relieve the thermal stresses and keep the backing more nearly flat during spraying.

\subsubsection{Penetrating Radiation (G. W. Scott)}

We ran a simple sensitivity test using $x$-ray fluorescence on tool steel shim material $(\sim 99 \% \mathrm{Fe})$. These tests yielded approximately $1 \%$ change in total counts per 0.001 in. change in material thickness in the range $0.008-0.011$ in. These results indicate that measurement of a 0.010-in. CoCrAlY coating will push the method very near its upper limit of thickness, and the achievable sensitivity will be near the lower limit of usefulness. Any further loss of sensitivity resulting from conversion to field use might render the method ineffective.

\subsubsection{Eddy Current Testing (G. W. Scott)}

Simple magnetic attraction tests show that the relative magnetic permeability of our as-sprayed CoCrAlY coatings is between 1 and 1000 . The magnetic attraction of a free-standing CoCrAlY layer is slightly less than that of an equivalent thickness of tool steel, which has a relative permeability of approximately 1000.

We have made a number of calculations to design a throughtransmission eddy current measurement technique for both the relative permeability and electrical resistivity of free-standing CoCrA1Y layers. We obtained a rough, though usable fit for permeability in the 1-1000 range, using 0.060 1n. radius coils at 10 and $100 \mathrm{kHz}$. We are still working on the resistivity; it will have to be fitted over short ranges of permeability. The correct fit to compute resistivity can be determined after an initial estimate of permeability is made.

We are awaiting the availability of a dual frequency eddy-current instrument to make the initial measurement. 


\subsection{Fossil Energy Welding and Cladding Program \\ D. P. Edmonds, J. J. Woodhouse and J. D. Hudson}

During this reporting period we have emphasized the evaluation of type $320 \mathrm{Cb}$ stainless steel clad deposits. Earlier results indicate that as the nickel concentration of these materials decreases, the tendency toward fissuring of the deposit increases. Therefore, we have prepared specimens for metallographic evaluation to test this hypothesis: These specimens will be investigated using optical metallography, microprobe, and scanning electron microscopy. Also, we are considering the use of Auger spectroscopy of these specimens to determine unusual surface concentrations of any elements where cracks occur. The results from this investigation will hopefully give us a better understanding of the cracking mechanism in these materials.

\subsection{Fireside Corrosion of Atmospheric-Fluidized Bed Combustor Tubes}

T. G. Godfrey and J. H. DeVan

\subsubsection{Flui.iDyne 1500-hr Test}

Examination of all samples from the 1500-hr test in the Fluidyne AFBC has been completed and the report covering the final 1000-hr portion has been received from FluiDyne. This essentially completes the data package, and preparation of a topical report on the 1500-hr experiment is in progress.

\subsubsection{Follow-On 3000-hr Test at Fluidyne}

Final preparation of both the new and re-inserted high temperature tubes and the new composite ( $21 / 4 \mathrm{Cr}-1 \mathrm{Mo} / 304$ stainless steel). low temperature tubes was completed, and the tube array has been placed in the bed following the trial shake-down run. The first 500-hr portion of the 3000-hr test was initiated on May 1, 1978. Initial operation has been uneventful and all conditions are within the target ranges.

\subsection{Failure Analysis and Prevention}

R. T. King

\subsubsection{Inspection Assistance to SRC, Wilsonville, Alabama, (G. W. Scott)}

We have completed machine work and metallography on the ultrasonic test blocks cut from the "old" lower head that was removed from the Wilsonville SRC dissolver tank. We are awaiting the arrival of low 
frequency transducers now on order to make ultrasonic tests on the blocks and determine the usefulness of ultrasonic methods with these materials.

Metallography shows that the $2.5 \mathrm{in}$. wall of the vessel has two well-defined regions of different grain structure. On the outside, grains are columnar and radially oriented. On the inside, grains are equiaxed, with no preferred orientation. The radius at which the interface between grain types occurs varies with axial position along the specimens examined. (These specimens were made by axial cuts, along or parallel to planes containing radii of the vessel, and hence do not show the circumferential variation of the grain-type interface.)

We have seen similar grain structure variations in other cast steel pipe, 1 and there are significant differences between the deformation behavior of these structures and that of structures made of isotropic materials. The effects of the grain structure variation on vessel wall measurement will probably be: (1) inability to make random absolute wall thickness measurements, since the acoustic velocity changes with the grain structure and the interface location is unknown; leading to (2) restriction of monitoring to specific points on the vessel where repetitive measurements can be made over a period of time to see if changes occur.

\subsubsection{Examination of In-Bed Components from Rivesville AFBC (T. G. Godfrey)}

Examination of 68 samples of in-bed heat exchanger surfaces and tubebundle supports extracted during the recent shutdown of the Rivesville AFBC has begun. Small boat samples were taken from Cell A top (2 $1 / 4 \mathrm{Cr}-1 \mathrm{Mo})$ and bottom $(1 / 2 \mathrm{Cr}-1 / 2 \mathrm{Mo})$ in-bed tubes, cell B top (2 $1 / 4 \mathrm{Cr}-1 \mathrm{Mo}$ ) and bottom (304 stainless steel) in-bed tubes, and cells $A, B$, and $C$ support hangers (Inconel 601). The fireside corrosion of all tube materials appears to be minimal with no evidence of sulfidation attack. Oxide scales are well-developed and intergranular corrosion is barely detectable. Sulfidation was observed only on the Inconel 601 in cell $\mathrm{B}$ and extended to a maximum depth of approximately $75 \mu \mathrm{m}$ ( $\sim 3 \mathrm{mils}$ ) only on several samples: Other support hanger samples showed intergranular corrosion/oxidation to depths of approximately $125 \mu \mathrm{m}$ ( $\sim 5 \mathrm{mils})$ under the oxide layer. We expect to conduct microprobe examinations of selected tube and hangar specimens.

\footnotetext{
1B. R. Dewey et al., "Applicat1on of Anisotropic Elasticity to Centrifugally Cast Piping", ORNL/TM-5994, October 1977.
} 


\title{
4. ALKALI METAL VAPOR TOPPING CYCLES
}

\author{
R. S: Holcomb
}

\subsection{Gas-Fired Potassium Boiler}

R. S. Holcomb, D. B. Lloyd, and R. H. Guymon

The objective of this work is to design, construct, and test a fullscale potassium boiler tube bundle and burner module on water and then potassium to determine their performance operating characteristics.

\subsubsection{Technical Progress}

All work necessitated by the installation of the mixing tee in the potassium return line was completed, and the boiler was refilled with potassium. Operational testing was resumed at a burner power of $0.97 \times$ $10^{6} \mathrm{Btu} / \mathrm{hr}$ and continued to a power of $3.1 \times 10^{6} \mathrm{Btu} / \mathrm{hr}$.

At the lower powers, the system operated smoothly and no problems were encountered in maintaining an acceptable temperature distribution. As the power to the burner was increased, the temperature of the potassium liquid flow from the condenser to the boiler decreased due to the proportionately larger amount of subcooled condensate mixed with the high-temperature liquid which is carried over from the boiler to the condenser. This low temperature liquid return can cause unacceptable thermal stresses in the piping system at the point where the liquid return line penetrates the vapor line between the boiler and the condenser. As operation continued, we also saw evidence that the argon vent lines were beginning to plug. The system was shut down and the potassium returned to the drain tank after a total of about seven hours operation.

The argon vent lines from the condenser were cleaned of accumulated potassium, and the potassium in the fill and drain tank was purified by heating it to about $1250^{\circ}$ for two days. A new pilot/ignition tube was assembled and installed in the burner to replace one that had become damaged during operation.

Recharging of potassium to the boiler was begun after the above maintenance operations, but after about half of the inventory (500 pounds) had been transferred, one of the valves in the transfer line became plugged.

In an effort to determine the cause of the plug, we withdrew a sample of potassium from the bottom of the drain tank and analyzed it for oxygen. We also dissolved a portion of the sample with ammonia and inspected the residue for particulate matter. 
The oxygen analysis indicated an oxygen content between about 15 and $30 \mathrm{ppm}$. This amount of oxygen in potassium is considered to be well below the level where one would expect to encounter corrosion problems and is also far below the oxide solubility limit. When the residue from the ammonia solution was examined, a number of small particles was discovered. The particles range in size from about 0.005 in. to roughly 1/32 of an inch. A spectrographic analysis was made of the particles and of several other small particles also recovered from the potassium. The particles apparently consist of varying amounts of several different materials. With only a few exceptions, the analysis appears to be consistent with what one might expect to obtain after operating a system of this nature. No single, probable source of the particles is evident from this analysis.

In an effort to avoid further plugging difficulties, a bypass filter system has been designed and fabricated and is currently being installed in the fill line immediately above the fill and drain tank. In the future during all charging operations, the potasstum will be filtered through the 100 mesh wire cloth in the new filter. During the present shutdown, insulation was applied to the bottom two-foot length of all of the condenser tubes on the lower section of the condenser and to the bottom ring header. This was done to minimize the condensate subcooling. Additional heaters and insulation have been applied to the argon vent lines to reduce the problems previously encountered with potassium plugging of these lines. 


\section{COAL EQUIPMENT TEST PROGRAM}

J. M. Holmes and R. E. MacPherson

Work under the Coal Equipment Test Program (CETP) is current1y divided into four sections:

- Critical Equipment for Demo Plants

- Coal Feeder Test Program

- Survey of Industrial Capability for Coal Handling Equipment

- Coal/Solids Handling and Feed Systems Program Plan

\subsection{Critical Equipment for Demo Plants}

J. W. We1.1s and D. E. Reagan

Negotiations continued with two DOE Demo Plant contractors and their subcontractors concerning non-disclosure agreements for use by TRW in their CETP study. Negotiations between Memphis Light, Gas \& Water Division (MLGW) and its subcontractors are currently in progress. All of the negotiations with Illinois Coal Gasification Group (ICGG) have been completed, and transmittal of the process information will be made as soon as releases are obtained by ICGG from their subcontractors.

As a result of discussions with DOE, a decision was made to reappraise the TRW study of demo plant critical components. The revised program included completion of the report using the information currently available and a reduced level of effort. TRW has submitted a revised scope of work, schedule and cost estimates to complete the study: Agreement on the revised contract is expected during May 1978, and work is continuing on a reduced staff level as requested by ORNL. Technical progress included:

- Four Tentative Test Loops were defined for testing components at "Pilot-Sized" levels. These Tentative Test Loops were transmitted to six potential test facilities which had expressed interest in the program. These six facilities are:

(1) Battelle Pacific Northwest Laboratories

(2) Ceneral Atomics Company

(3) Ames Laboratory

(4) Pittsburgh Energy Research Center

(5) Liquid Metals Engineering Center

(6) Oak Ridge National Laboratory.

-Work was completed on the summary of Industrial Failure Analysis Data for the Draft Final Report.

- At the request of ORNL, TRW provided input and comments on a preliminary draft version of Facility Needs and Capital Cost for Conal Conversion Equipment Testing for DOE. 
The COGAS process simulation work was finished and documented. A memorandum prepared by J. W. Wells provided: a complete description of the computer program, the assumptions that were used, the methods for solving the problem, input data, and results. A flow diagram accompanying the memo showed the relationships between flow streams associated with the 15 processing units. Results. from the program included the flow rate, composition, temperature, and pressure for each stream.

\subsection{Coal Feeder Test Program}

B. T. Thompson

Three trips were made to obtain background information for use in a feasibility study and preliminary conceptual design of a pilot scale (5 tons coal per hour) dry coal feeder test facility. A revised work statement was prepared for review that lists the design and construction activities required for a feeder test facility. Work continued on the flowsheet development and equipment definition for a feeder test system.

Pittsburgh Energy Research Center (DOE-PERC) was visited to discuss the use of lock hoppers as high pressure feeders and as pressure letdown devices. A Petrocarb lock hopper system is used in the Synthane coal gasification pilot plant as a feeder designed for 1000 psig operation. Another type lock hopper was installed but not used for pressure let-down. The pressure let-down system in use involves flow of a wet char slurry through a choke valve.

Trips were made to General Atomics at San Diego, CA, and Rocketdyne in Canoga Park, $\mathrm{Ca}$. The General Atomics visit was made to examine potential sites for a coal feeder testing station and to obtain information on the related work at General Atomics. The Rocketdyne visit was made to discuss the possibility of installing one of the DOE developmental coal feeders in Rocketdyne's flash coal hydrogeneration process and to learn of their progress in developing high temperature, high pressure, multi-stage coal slurry pumps. The DOE coal feeders do not appear to be available in time for use as the primary feeder in Rocketdyne's process. Rocketdyne is in the second year of developing their proprietary coal slurry pump for the Electric Power Research Institute (EPRI); their goal is operation at $2500 \mathrm{gpm}, 3000 \mathrm{psig}, 550^{\circ} \mathrm{F}$ using a 12-stage pump to handle a 50 weight percent coal slurry.

\subsection{Survey of Industrial Capability for Coal Handling Equipment}

F. C. Zapp, O. W. Thomas and M. D. Silverman

The statement of work for the equipment survey is being reviewed and revised to reflect recent decisions by DOE/FE-CC to place more emphasis on coal liquefaction technology. A first draft of the preliminary criteria for preparation of flow sheets of the conceptual 
designs of commercial coal handling-preparation and ash/slag removal systems was completed and is being reviewed prior to final issue. A preliminary 1 isting of coal handling-preparation and ash/slag removal equipment (including an identification code) was completed and issued for review and comment. This list and a response matrix of specific data will be incorporated in the questionnaires to be sent to industrial equipment firms.

A trip was made to the Pittston Company in Lebanon, VA, on April 12, 1978, to visit their Moss \#3.Coal Preparation Plant and Coal Testing Laboratories. Actual coal handling and preparation operations were observed, and valuable discussions were held with key personnel. This plant was producing 25,000 tons/day of product coal and requires up to 50,000 tons/day of run-of-mine (ROM) coal feed.

\subsection{Coal/Solids Handling and.Feed Systems Program Plan}

R. E. MacPherson, J. M. Holmes and J. E. Jones Jr.

ORNL has participated in the preparation of a comprehensive program plan for the development of improved coal/solids handling and feed systems. The plan was prepared by the Jet Propulsion Laboratory, and the basic information was developed by:

- Morgantown Fossil Energy Research Center

- Oak Ridge National Laboratory

- Pittsburgh Fossil Energy Research Center

- The Jet Propulsion Laboratory

-Argonne National Laboratory.

The program plan provides for the development of components and systems at the pilot-scale, and in some cases demonstration-scale, over a six-year period for incorporation into demonstration and commercial plants. 


\section{ATMOSPHERIC FLUIDIZED BED COAL COMBUSTOR FOR COGENERATION (AFB CCC)}

R. S. Holcomb and R. H. Guymon

\subsection{Combustor Specifications}

A meeting was held with DOE-FE in Washington on April 5-7 in which the request for proposal and performance specifications for the combustor were revised. A new draft was then prepared incorporating the revisions and was submitted for review. A few minor changes were requested in a meeting held at DOE-FE on May 2, and the RFP package was approved for release with those changes.

\subsection{System Design}

One of the vendors that had been contacted about design of the ash handling system visited ORNL and submitted a preliminary proposal. The proposal included some alternatives and these were discussed. They agreed to submit a proposal and cost estimate for two systems: (1) partial in-line cooling with transport air and hot ash storage; (2) cooling with ash cooler and cool ash storage.

A proposal for the ash handling system has not yet been received from the second vendor that had agreed to submit a design.

\subsection{Coal Feeder Development}

The preliminary test of the coal feed system feeding limestone was completed. The performance of the coal feed system was excellent over the entire range of. feed rate and expanded bed height. The limestone feeder was also operated feeding limestone to a single nozzle at the center of the bed. It performed well over the entire range of expanded bed height.

A quantity of new limestone has been ordered for use in the bed for the test program. When the limestone is received, the coal feeding tests will be run.

\subsection{Materials Testing}

The specimen tubes were installed in the Fluidyne combustor, and the $3000 \mathrm{hr}$ corrosion test was begun on May 1. Further information can be found in Section 3.4 . 


\section{ENGINEERING STUDIES AND TECHNICAL SUPPORT}

J. R. McWherter

Engineering studies and technical support are provided primarily for the DOE/FE Division of Coal Conversion. The effort includes: the development of analytical tools for use in the evaluation of processes and equipment; the technical and economic evaluation and comparison of coal conversion processes and subprocesses on a uniform basis; surveys of the need for coal conversion equipment and the capability of industry to provide such equipment; and studies of the magnitude and control of coal conversion plant emissions.

\subsection{Process Modeling}

R. Salmon, O. L. Culberson, and D. M. Lister

\subsubsection{Contract Objective}

The objective is to assist DOE/FE in its plan for computer analysis and computer support for coal conversion studies. This includes assistance to Purdue and Lehigh Universities in the development of computer programs for this plan. Physical property data are being collected and computerized primarily by Purdue and will be used in support of programs prepared by both universities. Purdue's general design program will aim at material and energy balances, equipment size and costing, plant capacity, and general economics. Lehigh's dynamic simulation programs will address plant design primarily from the standpoint of process performance during transient operations, but can also be used for steady-state conditions. A single flowsheet will be selected to assess the operability and complementary utility of both design programs.

\subsubsection{Status Summary}

Revised versions of the physical properties and material balance programs were received from Purdue. Action was initiated to convert the programs for implementation on the ORNL IBM-360 system. It is expected that this will be completed in about-a month.

A meeting was held at Lehigh Unlversity on April 26 to discuss the schedule for the delivery of the various remaining parts of the code packages from Lehigh to ORNL, to enable the ORNL Computer Sciences Division to schedule their work load and personnel for the implementation of the programs. A tentative delivery schedule was agreed upon. Other items discussed were preparation of users' manuals and possible Lehigh participation in training seminars. It was agreed in principle 
that it would be desirable for Lehigh to conduct a short course in the use of their program in the summer of 1979 provided that an acceptable schedule and funding can be arranged.

ORNL completed a simulation of the COGAS gasifier in connection with another project. The Fortran program has been documented and will be transmitted to Purdue and Lehigh shortly.

The ORNL program for thermal design of a shell and tube heat exchanger, which was described in our previous monthly report, was used to design several large gas-to-gas exchangers for the underground coal gasification process evaluation currently being conducted at ORNL.

\subsection{Synthetic Fuels Process Research Digest}

F. M. O'Hara, Jr. and R. W. Glass

\subsubsection{Contract Objective}

The objective is to provide continuing technical assistance to DOE/FE by preparing digest reviews of current or potential subjects relating to coal conversion technology.

\subsubsection{Status Summary}

Progress on second issue articles continued. Typesetting and drawings were completed for the CSF article and galley proofs were prepared for circulation and revision. Editor review and author revisions were completed on the SRC-II article; text and illustrations were submitted for typesetting and drawing. Final materials for preparation of the Fischer-Tropsch article were obtained through intra-library loan.

Requests from DOE-FE for preliminary copies of articles in preparation were filled, and work on the Digest was effectlvely halted pending their review. The review impacted significantly on the CSF article and less so on the SRC-II article; work on the two articles will resume with consideration of the review comments. 


\subsection{Survey of Industrial Coal Conversion Equipment Capabilities}

W. R. Williams. T. M. Andress, W. F. Boudreau, W. A. Bush, W. R. Gambill, D. W. Hatcher, J. R. Horton, J. P. Meyer, W. R. Reed, C. B. Tolliver

\subsubsection{Contract Objective}

The objective of this project is to conduct surveys of industrial equipment capabilities that will identify the present capability of industry to supply the equipment needed. The project will also determine research and development needs, including lead time requirements, for producing equipment of advanced design for the various unit operations of critical importance to the Division of Coal Conversion (CC).

\subsubsection{Status Summary}

The report covering FY-1977 activities on rotating components (ORNL/TM-6074) has been published and distributed. The valve report is to go to print during the first week of May. Printing will take about 3 weeks. The reports on hcat recovery and high temperature, high pressure gas purification are being proofread and are awaiting $f$ inal approval before editing. These reports should be out the last week of May or first week of June.

Letters of inquiry concerning equipment operating parameters in demonstration plants were mailed to DOE project managers on April 7 . At least 2 of 5 project managers have forwarded the requests to appropriate individuals for their response.

A visit was made by D. W. Hatcher to the Gray Tool Company (Houston, Texas) to discuss their Grayloc connectors, which have been used successfully in several pilot plants. These connectors are available in sizes and for pressure/temperature ratings suitable for commercial size plants. Materials readily available for manufacture of connectors include carbon steel, stainless alloys, Inconel, Hastalloy, titanium, and zirconium. Connectors can also be made from carbon steel, then coated with hard chrome platings for slurry service.

Prellminary work for the let-down valve, expansion joint, and mechanical connector surveys has been completed. Survey forms will be mailed to manufarturers of these itemo during May.

Additional information on projected coal conversion capacity has been obtained and is being reviewed. Projected market demand for equipment should be determined by mid-May.

A letter to manufacturers of hot-gas expanders was drafted; it concerns expander development programs and associated costs, and prices of existing expanders. Other letters concerning cost data on parkage oxygen systems and on compressors were also drafted. 
Positive letter responses have been received from 7 firms which were contacted for price information on components (tubing, plate, and forgings) for heat exchangers. Tabulated price data will be provided to Royes Salmon (Chem Tech Division) for use in a computerized estimating code, which will be a useful reference for this survey.

Equipment operating experience was discussed during visits to Synthane and BI-GAS pilot plants in Bruceton and Homer City, Pennsylvania, respectively. Discussions with Conoco personnel were held in Library, Pennsylvania, concerning the $\mathrm{CO}_{2}$ Acceptor pilot plant operating experience. Discussions concerning pumps, expanders, and heat exchangers were held with Union Carbide equipment specialists in South Charleston, West Virginla.

Trip reports concerning the above-mentioned visits (which were made during the period of April 11-19) are being prepared. Some overview comments follow.

1. Pumps - Poor pump performance has been. largely due to secondary effects. In one facility, misalignment of pumps resulted in a number of bearing and seal failures. High iron content in seal flushing water has also caused problems; it was recommended that high quality water (even boiler grade) be used for seal flushing. In several instances, plant design called for relatively clean liquid streams, but poor cyclone performance led to excessive particulate carryover and, subsequently, to high erosion rates in pumps not designed for slurry services. One gasifier feed system (BI-GAS) used reciprocating pumps, which performed acceptably (packing and plungers were not damaged, but valves and valve seats were severely worn after approximately 200 hours).

2. Compressors - Pilot plant compressors were generally of reciprocating design; however, commercial plants will generally use centrifugal compressors. Oxygen is presently being supplied as a liquid and is being pumped to system pressure (or higher), then vaporized.

3. Expanders - An expander is required to ensure the economic viability of the $\mathrm{CO}_{2}$ Acceptor process. In order to test expanders of sufficient size to provide useful data on commercial scale equipment with a representative supply of particulate-laden gas, a demonstration plant is required.

4. Solids Handling - Solids recirculation and metering is of great concern in all pilot plants.

5. Valves - Pressure reducing valves arranged in series and taking a 250 psi pressure drop per stage have eroded much less severely than single valves taking a 600 psi drop.

6. Heat Recovery - Few problems have occurred. Fines carryover, due to poor cyclone performance did cause some tube plugging. 
7. Cyclones - Poor cyclone performance led to pump erosion and heat exchanger tube plugging. Condensation of tars in the Synthane cyclone resulted in its being plugged; this problem was resolved by deep bed injection of coal (as opposed to initial free fall of coal from above bed injection). Apparently, much of the tar is now thermally cracked and the of $\mathrm{f}-\mathrm{gas}$ temperature is now sufficiently higher $\left(1115^{\circ} \mathrm{F}\right.$ versus $700^{\circ} \mathrm{F}$ ) to prevent tar condensation.

Trips to IGT facilities (HYGAS and HYGAS Steam-Iron) are scheduled for May 9 and 10. Visits are also being planned to Fisher Control Company (let-down valves), and Zallea Brothers (expansion joints).

\subsection{Flash Hydropyrolysis}

S. P. N. Singh

\subsubsection{Contract Objective}

The objectives are to perform a preliminary technical and economic assessment of the Cities Service and the Schroeder-Spencer Chemical Company flash hydropyrolysis processes and to determine if a more detailed engineering evaluation is justified.

\subsubsection{Status Summary}

The draft final report titled Scoping Study on Two Flash Hydropyrolysis Processes (ORNL/TM-6265) has been edited by our technical editing staff and is presently being prepared for final publication.

\subsection{Hot Gas Purification Processes}

M. S. Edwards and J. P. Meyer

\subsubsection{Contract Objective}

The objective of this project is to investigate the present stateof-the-art hot gas cleanup processes. The application of most interest is the removal of contaminants from coal-derived fuel gas prior to firing combined cyrle turbines.

In this work, a survey of the available and developmental processes for the removal at high temperature of various contaminant materials (particulate, sulfur, nitrogen, and alkali metal compounds) has been conducted. Based on the data obtained in this work, from a variety of sources, an analysis has been performed to evaluate the performance of a number of potential cleanup processes in light of the overall system needs. 


\subsubsection{Status Summary}

The final report, ORNL/TM-6178, A Survey of Processes for High Temperature - High Pressure Gas Purification, which includes a review of the available systems for the removal of particulates and sulfur and nitrogen compounds to levels compatible with high temperature - high pressure turbine operation has been approved by DOE and is currently undergoing technical editing prior to publication.

\subsection{State-of-the-Art Review of Heat Recovery Processes}

W. R. Gambill and W. R. Reed

The objective of this review has been to survey, appraise, and catalog the processes for heat recovery which industry offers or plans to offer or may logically be expected to offer. These processes are applicable to the recovery of heat in process streams from primary exothermic coal conversion and combustion process steps. Simplc unaugmented application of conventional heat transfer equipment are not included. The review distinguishes between presently installable technology, near term developable technology, and future prospects. Consideration is given to possible transfer of technology from other industries. The final report for this work, State-of-the-Art Review of Heat Recovery Processes, ORNL/TM-6222 is now in publication and will be issued soon.

\subsection{Assessment of a Moving Bed System for Cleanup of Raw Gasifier Gas}

R. W. Glass, W. R. Gambill, and R. H. Lamb*

The objective is to assess the feasibility of a proposed moving bed system for removal of sulfur and particulates from raw gasifier gas. The assessment considers two basic hot gas treatment systems, with each system specifically addressing sulfur and particulate removal. The reference system incorporates a panel filter for dust removal and fixed bed adsorber/regenerator units. The project system incorporates a moving bed filter/adsorber unit, with fluid bed regeneration of the recycled filter/adsorber media. Both syslems pruduce high pressurc steam (waste heat boiler) from the regeneration off-gases. The assessment includes simple equipment flowsheets and material balances for both systems, and comparative economics are developed. Final typing and review of the study report has been concluded and the draft forwarded to editing and publication.

\footnotetext{
* Consultant.
} 


\subsection{Technical/Economic Assessment of Hydrogen Production by} the Steam/Molten Iron Process

R. W. Glasis and L. Seglin*

\subsubsection{Contract Objective}

The objective is to determine if there is sufficient incentive to develop the subject process for production of hydrogen from coal. The project considers specifically the comparison of the subject process (a molten-iron/steam concept) to the more conventional concepts employed in the Koppers-Totzek and Bi-Gas processes. All three processes are considered as part of an overall integrated SRC-II system. Process flowsheets, system costs, and product distributions will be described for each case and comparative economics developed. A development program for bringing the molten-iron process to the state of commercial availability will be addressed.

\subsubsection{Status Summary}

The draft report was completed and reviewed by the DOE Project Manager. Comments are being considered and discussion on revisions to the report are in progress.

7.9 A Study of Effluent Control Technologies for Hydrocarbon and Carbon Monoxide Emissions from Coal Conversion Plants

J. F. Fisher and G. R. Peterson

\subsubsection{Contract Objective}

The objective of this project is to provide a technical and economic comparison of processes available for the control of gaseous hydrocarbon (HC) and carbon monoxide (CO) emissions. Control of sulfur emissions is not considered in the present scope of study. The Lurgi gasification process is considered as the reference emission source, and comparisons of control technologies consider incineration as the reference control system. This project is supported and directed by the DOE Division of Environmental Control Technology.

\footnotetext{
*onsultant.
} 


\subsubsection{Status Summary}

Processes examined for decontaminating the tail gases included recovery and recycle methods as well as those that convert the contaminants to harmless products. The most recent proposed EPA emission standards for carbon monoxide and nonmethane hydrocarbons were used as upper limits for the residual contaminants in the treated effluent. Limited assessments of the technical and economic feasibility of ten processes were made. Of the processes studied, the two most promising were found to be incineration in a coal-fired boiler and catalytic incineration. Neither of these methods has been employed commercially under the projected operating conditions, although both are employed in other industries to carry out the basic reactions involved. Total capital and operating costs on a 20-year discounted cash flow basis with $100 \%$ equity financing and $12 \%$ annual after-tax return on investment were estimated to be $4 \mathrm{C} / \mathrm{MMBtu}$ of SNG for the coal-fired boiler and 5c/MMBtu for the catalytic case. However, the uncertainties in the costs are greater than the indicated cost differentials. The cost of incineration in a gas-fired boiler using sulfur-free medium-Btu gas was estimated to be 11c/MMBtu of SNG. All other routes examined were several times more expensive than this.

The final draft report titled Control of Hydrocarbon and Carbon Monoxide Emissions in the Tail Gases from Coal Gasification Facilities (ORNL/TM-6229) was sent to DOE for final review. Technical editing of the report is in progress.

\subsection{Environmental Controls for Low-Btu Gasification}

S. P. N. Singh, M. S. Edwards, J. F. Fisher, G. R. Peterson, and R. Salmon

\subsubsection{Contract Objective}

The objective of this project is to evaluate the various environmental control processes that might be used in connection with low-Btu gasification facilities and to determine the economic tradeoffs for various processes and levels of control.

The project is divided into two phases: Phase I consists of Tasks 1 through 5 of the work statement, and covers the preparation of a detailed work plan and the selection of gasification and environmental control processes for use in the study. Phase II consists of Tasks 6 through 8 in the work statement, and covers the collection and analysis of technical and economic data on the various environmental control processes and the preparation and analysis of flowsheets showing overall systems of environmental control processes used with various gasifiers. 


\subsection{0 .2 Status Summary}

A report is presently being drafted to present the results of the work performed for Tasks 6 and 7 of the project. Tasks 6 and 7 collectively consist of developing technical and process cost information on 25 environmental control processes that may have potential application in the production of environmentally clean low-Btu gas from coal. The 25 environmental control processes were selected in Task 2 of the project. The draft report on Tasks 6 and 7 of the project is scheduled. to be issued to DOE/FE-DET by July 1, 1978 .

Consistent with Tasks 6 and 7 objectives, write-ups have been drafted for the following acid gas treating and sulfur recovery processes: Claus, Stretford, and DEA, and for the following by-product recovery processes: Chevron WWT, Phosam-W, Phenosolvan, and the Jones \& Laughlin Dephenolization process. Draft write-ups for the other chosen processes are at various states of completion.

Some difficulty is being experienced.in developing the required information on waste water treating processes. There is a general lack of established standards for the levels of various contaminants likely to be present in the effluent waste water from coal gasification facilities. Also, there is a lack of available commercial data on the performance of some of the waste water treating processes for treating coal processing plant waste waters. Despite these difficulties, it is believed that a satisfactory section on waste water treating processes can be developed.

\subsubsection{Open Items}

We have not yet received written approval from DOE/FE-DET to proceed with Phase II of the study, as required by the project work statement. However, verbal approval to proceed with Phase II was given at the December 7, 1977 meeting, with written confirmation to follow.

\subsection{Support of the Office of Initial Operations (OIO) \\ B. Niemann, J. F. Fisher, H. F. Hartman, and W. R. Reed}

\subsubsection{Contract Objective}

The objectives of this project are: (1) to perform rapid reaction reviews and analyses of documents provided by DOE on Coal Conversion Demonstration Plant projects with appropriate follow-up as requested; (2) to produce design checklists and conduct requested evaluations in the DOE/FE/OIO's areas of responsibility which include considerations of start-up, safety, environmental pollution, maintainability, and reliability; and (3) to develop guidelines for the preparation of safety, operation, and ma1ntenance manuals. 


\subsection{1 .2 Status Summary}

A rapid review of a NIOSH draft document entitled "Criteria Document: Recommended Standards for Coal Gasification Plants" was performed. The document was reviewed by representatives of the following organizations: Chemical Technology, Plant and R\&D Industrial Hygiene, Maintenance, Operations, Utilities and Engineering. The major comments dealt with the difficulties involved with attempting to set specific engineering and work practices for the gasification industry. The recommended changes suggest that these standards should be more appropriately termed "guidelines." A document containing 108 comments was forwarded to DOE/FE/OIO.

Work continues on developing specific design checklists strictly applicable to the specific process areas of coal conversion plants. 
8. PROCESS AND PROGRAM ANALYSIS

J. R. McWherter

Process and program analysis studies are being conducted for the DOE Fossil Energy Engineering Economics and Standards Section of the Division of Program Control and Support. This effort includes research studies on most of the coal conversion and utilization processes. The program objective is to provide on a consistent basis, technical and economic evaluations of competing processes and systems for coal conversion and utilization.

\subsection{Low Btu Coal Gasification}

H. F. Hartman, D. E. Reagan, and J. P. Belk

\subsubsection{Contract Objective}

The objectives of this study are to survey the low Btu coal gasification processes, select the most promising processes, and provide technical and economic information on the competing processes.

\subsubsection{Status Summary}

Work was done on the draft report entitled "Low Btu Coal Gasification Processes." Volume 1, "Summary, Screening and Comparisons," was prepared for distribution to Department of Energy and ORNL reviewers. This first volume provides a summary of coal gasification processes and describes the approach and results of selecting processes for detailed study. The report contains a list of 99 processes that were surveyed and a concise summary of 58 processes. Comparisons are shown for 21 selected processes and include status, gasifier capacity, operating conditions, efficiencies, coal feed requirements, and coal feeding methods. Process related considerations are discussed and include process applications, problem areas, economic considerations, as well as environmental considerations. Volume 2, "Selected Process Descriptions," is being prepared and contains information on the selected 21 coal gasification systems. Work continued on changing the process descriptive sections based on comments by the process proponents. The Vol. 2 draft report will be completed and distributed for review in May. 


\subsection{Direct Combustion}

E. C. Fox and T. D. Anderson

\subsubsection{Contract Objectives}

The purpose of this study program is to assist DOE/FE in their effort to develop a national strategy to increase the near-term use of coal through direct combustion; the applications of interest in this study are the small-to-moderate industrial user and the large residential/commercial user. The following objectives will be accomplished:

1. Identify and quantify the important factors restricting the use of coal in the sectors of interest.

2. Evaluate potential technological and institutional solutions to the probleme identifled in (1) above.

3. Make recommendations to DOE/FE relative to the most promising approaches to increasing the near-term use of coal.

\section{2 .2 Status Summary}

The technical and economic assessment of the barriers is complete, as is the evaluation of the alternatives - central steam systems and the area coal depot. The effort made this month has been compiling the final report and preparing for a review of the report. The review will consist of a one-day meeting in Oak Ridge in which the authors, sponsors and six industrial and commercial representatives will meet. The draft report is being sent to the industrial representatives who will review the report and provide comments on the content and recommendations for further work, if any is needed. 


\subsection{Advanced Power Conversion Systems}

G. Samuels and A. P. Fraas*

\subsubsection{Contract Objective}

The objectives of this project are to review selected major advanced power conversion systems and to assess these systems with respect to their basic R\&D status.

\subsubsection{Status Summary}

A total of eleven systems or components of systems were evaluated. Draft reports covering all of these topics (see tabulation below), an overall summary report, and an executive summary report have been completed and have received extensive reviews by persons especially know1edgeable of the various technologies involved. Five reports are now on mats and the remaining eight are undergoing typing, editing or makeup.

1) Summary of the Development of Steam Power Plants for Central Stations

2) R\&D Experience and Current Status of Development of Open Cycle. Gas Turbines

3) Summary of the Development of Open Cycle Gas Turbine-Steam Combined Cycles

4) Summary of the R\&D Effort on Open Cycle Coal-Fired Gas Turbines

5) Summary of the R\&D Effort on Air and Water Cooling of Gas Turbine Blades

6) Summary of the R\&D Effort on Ceramic Gas Turbines

7) Summary of the R\&D Effort on Closed Cycle Gas Turbines

8) Summary of the Work on the Supercritical $\mathrm{CO}_{2}$ Cycle

y) Summary of the R\&D Effort on Alkali Metal Vapor Cycles

10) Summary of the R\&D Effort on Open Cycle MHD Systems

11) Summary of the R\&D Effort on Fuel Cells

12) Comparison of Advanced Energy Conversion Systems on the Basis of $R \& D$ Experience

13) Comparison of Advanced Energy Conversion Systems on the Basis of R\&D Experience. Executive Summary Report.

* Consultant 


\subsection{In Situ Coal Gasification}

W. C. Ulrich and M. S. Edwards

\subsubsection{Contract Objective}

The objective of this program is to provide technical and economic evaluations of candidate processes for the conversion of coal in situ to fluid products presently of interest. During FY 1977, technical and economic evaluations of the linked vertical well process applied to subbituminous coal were addressed. Three alternative end product configurations were considered - electricity, SNG, and syngas. In FY 1978, an evaluation is being conducted of an in situ facility for producing gasoline from methanol via the Mobil-M process.

\subsubsection{Status Summary}

Equipment sizing calculations were completed for all major process units of the in situ syngas-to-gasoline facility. Results were tabulated on equipment list forms previously prepared. Utilities requirements for these units were also determined and tabulated. Units remaining to be sized include the steam generator and power plant, the oil and water treating plants, and the offsite facilities.

A bid was accepted from Davy Powergas, Inc. for supplying design and cost data for the methanol synthesis plant. It is expected that contract negotiations with Davy currently being carried out by our Purchasing Division will be completed by May 1, 1978.

\subsubsection{Open Items}

Publication of the FY-77 in situ work, Process Designs and Economic Evaluations for the Linked Vertical Well In Situ Coal Gasification Process (OKNL-5341) is pending further discussion with DOE/FE.

\subsection{Coal Beneficiation}

S. P. N. Singh and G. R. Peterson

\subsubsection{Contract Objective}

The objective of this study is to provide technical and economic evaluations of currently used and potential coal beneficiation processes. Project efforts culminated in a draft final report titled 
Survey and Evaluation of Current and Potential Coal Beneficiation Processes (ORNL/TM-5953) which was completed in October and forwarded to DOE for review and comments. The report summarizes the technical evaluations of currently used and several novel coal beneficiation techniques.

\title{
8.5.2 Status Summary
}

Publication of the project final report is pending resolution of comments with DOE/FE.

\author{
8.6 Gas Cleanup Studies \\ M. S. Edwards
}

\subsubsection{Contract Objective}

The objective of the gas cleanup study is to collect information on the technology and economics of processes for the removal of impurities (principally hydrogen sulfide) from fuel gas streams. High- and lowtemperature cleanup processes will be reviewed.

\subsubsection{Status Summary}

The draft report ORNL/TM-6077. Selection of Candidate $\mathrm{H}_{2} \mathrm{~S}$-Removal Processes Applied to Low-Btu Coal Gas, was sent to the Department of Energy on October 3, 1977. The report gives detailed process descriptions and cost data for seven methods of removing $\mathrm{H}_{2} \mathrm{~S}$ from a low-Btu coal-derived gas: MDEA, Benfield, Selexol, Sulfinol, Stretford, MERC Iron Oxide, and Molecular Sieve. Each of these processes was selected as representing a particular category of gas treating.

DOE comments on the draft report were received on February 8, 1978 and have been reviewed to determine what changes are needed in the report prior to publication. Pertinent DOE comments have been included and the draft report will be sent to in-house technical editing.

\subsection{HYGAS Modeling}

J. P. Meyer, G. C. Frazier, J. W. Wells, and J. P. Belk

\subsubsection{Contract Objective}

The objective of this project is to develop a computer model of the HYGAS gasifier. 


\subsubsection{Status Summary}

During the last month, work has progressed smoothly on the HYGAS modeling project. Advances have been made both in the conceptual area, that is the mathematical formulation of the model, and in the computational area, that is the development of the computer programs which incorporate these algorithms.

Conceptually, models have been obtained for the devolatilization of both Montana lignite coal and Illinois No. 6 coal. In the first case, use has been made of the work of Suuberg et $a 1^{1}$ at MIT while in the latter case, information has been provided by Reklaitis ${ }^{2}$ at Purdue. Because of the relatively high tar yield of Illinois No. 6 coal it would be desirable to have information on the thermal hydrocracking of coalderived liquids. Such information would allow us to obtain an estimate, albeit approximate, of the contribution of this mechanism to overall process yields. At this time, we are searching the literature to see if such information is available or can be approximated.

As previously indicated, one problem that we have encountered is that for the rapid rate methane formation model developed by IGT, a complete set of model parameters does not appear in the open literature. To overcome this hurdle, efforts have been made to parametrically determine this value from graphical information provided by IGT. In this way, a reasonable estimate of the unknown parameter has been obtained.

Computationally, a computer code has been developed which simulates the behavior of both the steam-oxygen gasifier and the high temperature reactor of the HYGAS pilot plant. In this development, only the kinetic steps of slow rate hydrogasification and rapid rate methane formation have been included. Preliminary results indicate that the heat loss from each reactor has a significant effect on reactor yields. Further work is needed to fully explore the implications of this observation.

In addition to this work, another computer code is being developed which will model solely the behavior of a single bed. Included within this algorithm will be the steps of devolatilization, rapid rate methane formation, and slow rate hydrogasification. Computationally, inputs to the model will consist of: the solids and gas stream to the bed, the bed space time and any heat losses that may occur. The motivation for the development of this code stems largely from the fact that such a model, when fully developed, can be recursively used to form a mulc1ple bed model.

In other areas, work has begun on a systematic analysis of HYGAS pilot plant data, where available. Considerable care is being taken to clearly ascertain the composition of the feed material to the pilot plant reactor. In cases where the feed coal has been pretreated, it is important to obtain both an ultimate and proximate analysis of the feed material. In this regard, we are naturally constrained by availability and accuracy of IGT data. 


\title{
8.7.3 Problem Areas
}

A completely accurate description of the HYGAS pilot plant will be limited, in part, to the extent to which we are able to characterize the thermal hydrocracking of coal-derived liquids. The impact of the mechanism will be proportional to the tar yield of a particular coal.

\subsubsection{References}

1. E. H. Suuberg, W. A. Peters, and J. B. Howard, "Product Composition and Kinetics of Lignite Pyrolysis," Paper presented at 173rd National Meeting of ACS, Vo1. 22, No. 1, March 21-25, 1977, New Orleans, La.

2. Personal communication, G. V. Reklaitis, Purdue University, West Lafayette, Ind.

\subsection{Liquefaction}

\author{
J. R. McWherter
}

\subsubsection{Contract Objective}

The objective of this project is to provide technical and economic evaluation of coal conversion liquefaction processes. Ralph M. Parsons Company is working under subcontract on the project with J. B. O'Hara as Project Manager. Major tasks included in the subcontract are: (1) a Survey of Liquefaction Processes, and (2) a Detailed Review of High Potential Liquefaction Processes.

\subsubsection{Status Summary}

The detalled review is continuing of high potential liquefaction processes. The information package for the H-Coal process was completed. This package contained, among other items, a block flow diagram with heat and material balance, dissolver elemental balance, high potential process evaluation data, manpower requirements, purchased utilities, water supply and effluent treatment, procedures for environmental control of air effluents, sulfur balance, and catalysts and chemicals cost.

Parsons also completed the information package for the CSF case; this contained the same items listed above for the $\mathrm{H}-\mathrm{Coal}$ case.

The description of the H-Coal case, including data sources, constructed cost bases, and process description sections, was revised. 


\subsection{High Btu Gas}

J. R. McWherter

\subsection{1 $1^{\circ}$ Contract Objective}

This subprogram is being analyzed under subcontract by the Scientific Design Company, Incorporated (SD) with A. S. West as Project Manager. The present work is divided into three phases as follows:

1. The objective of Phase $I$ is to provide technical and economic evaluations of competing processes, concepts and systems for the production of high Btu gas from coal.

2. The objective of Phase II is to monitor and analyze data from the HYGAS Pilot Plant.

3. The objective of Phase III is to perform a technical and economical evaluation of the Battelle Agglomerating Ash Burner Process for the production of medium Btu fuel gas, synthesis gas and hydrogen from coal. (The subcontract extension for this phase of the work has not yet been approved.)

\subsubsection{Status Summary}

Phase I - No additional work was done on this phase.

Phase II - The assignment of SD personnel to monitor the results from the HYGAS pilot plant near Chicago is continuing. After the start-up burner was lit on April 6, 1978, a number of steam leaks developed which required repair before the start-up could continue. In addition the water pipe which pierces the shell of the slurry dryer broke and flooded the space between the outside reactor wall and the slurry dryer. The unit was shutdown to repair this leak and the startup burner was relit at 730 hours on April 12. IGT expects to start feeding coal by April 12 or 13.

\subsection{Comparative Cost Estimates of Five Coal \\ Utilization Processes}

J. R. McWherter

\subsubsection{Contract Objective}

The objective of this study is to determine consistent investment costs for four different coal utilization processes plus a conventional coal-fired power plant. The study will consider a high sulfur bituminous coal, such as an Illinois No. 6 used for a $500 \mathrm{MW}$ power plant. Of 
the four coal conversion processes, two will consider scrubbing sulfur from the flue gases, the third. will consider atmospheric fluidized bed combustion with simultaneous entrapment of sulfur by injection of lime, and the fourth will consider a coal beneficiation process coupled with flue gas scrubbing. This study is being conducted under subcontract by Chem. Systems, Inc., with L. H. Weiss as Project Manager.

\subsection{0 .2 Status Summary}

The draft of the final report on this work is in preparation. This will be sent to DOE for comments. 


\section{FOSSIL ENERGY ENVIRONMENTAL PROJECT}

C. R. Boston

The Fossil Energy Environmental Project provides the Division of Coal Conversion with program assistance in the performance of environmental assessment functions related to the expansion of fossil energy conversion technologies, performs assigned technical assistance tasks, and conducts programmatic environmental investigations that are critical to the early realization of advanced fossil energy technologies.

\subsection{Stored Solids Study}

$$
\text { W. J. Boegly, Jr. }
$$

The Slagging Lurgi waste (250 pounds) arrived at ORNL on April 18, 1978. Initial chemical analys1s indicates the waste is about the same as the sample brought back from Scotland by $\mathrm{H}$. T. Jones (DOE). On April 14, 1978, the 35 drum shipment of Cogas waste left England by ship with an estimated arrival date of May 9, 1978, at Charleston, South Carolina. 0. A. Colitti (DOE) is attempting to get SRC I and II wastes.

Due to the unavailability of large amounts of waste (other than Cogas, and perhaps Hygas) the whole lysimeter program will be scaled down to use smaller amounts of waste. Preliminary discussions are based on obtaining from two to five drums of each waste. We are currently assessing the availability of these quantities.

As a result of discussions with $H$. T. Jones on April 17, SRC wastes are to be given high priority in future studies.

The eight barrels of coal described in the last Monthly Report are now at ORNL. The investigation of the leachate from coal storage piles is well underway with emphasis being placed on controlled laboratory experiments designed to investigate various factors believed to be important in determining leachate quality. A factorial experimental design is being developed and carried out which will determine three of these factors - coal type, coal size, and leaching technique. All other factors known to influence leachate quality, such as temperature of the coal, frequency of leachings, and $\mathrm{pH}$ of the applied rainwater, will be held constant in this first experiment. Each of the three factors under consideration will be investigated at two levels yielding eight experimental combinations. 
Large concrete lysimeters were delivered on April 20, 1978. We now have four stainless steel lysimeters (55 gallon drum size) and one open-sided coal leaching lysimeter.

Samples of the liquid phase of Hygas waste slurries were delivered to the Life Sciences Synthetic Fuels Program for toxicological studies. Leachates from various coal conversion wastes will also be provided for these studies in the future. :

\subsection{Environmental Monitoring Handbook}

\section{S. G. DeCicco}

Al1 review copies were returned. Comments were considered and appropriate revisions were made. Final editing, composition, and makeup filled the remainder of the month.

\subsection{Technical Assistance}

9.3.1 Interaction with demonstration plant contractors - S. G. DeCicco

There was no activity this month on the CONOCO, ICGG, or Grace/ Ebasco demo projects. On the Memphis Light, Gas, and Water (MLGW) demo project, comments on the March 21 work statement for the environmental task and the March 28 addendum were prepared and sent to DOE. 
10. MAGNETIC BENEFICIATION OF DRY PULVERIZED COAL

D. M. Eissenberg and E. C. Hise

\subsection{Objective}

The objective of this project is to develop and demonstrate a novel process for coal beneficiation by magnetic separation of pyrites and ash from dry pulverized coal.

\subsection{Status Summary}

Experimental work continued toward both characterlzing the distribution of the inorganic content of several coals as a function of the degree of pulverization and the size fraction, and determining the magnetic separability of the various size fractions. Effective cleaning of coal probably requires crushing finely enough to release the inorganic sedimentary deposits which, in many coals, have been shown to range down to sub-micron size. However, when these particles are released, they appear to be responsible for the agglomeration which, many investigators report, defeats attempts to magnetically process aspulverized coal.

Three coals pulverized by different processes were separated into size fractions and analyzed with the results shown in Table 10.1. It would appear that the more finely the coal is crushed, the higher the percentage of inorganic material released and separable on the basis of size. This could, however, be instead a function of the coal. It would further appear that, for some coals at least, air classification of the pulverized coal can both remove a significant fraction of the inorganic material as well as prepare the bulk of the coal for magnetic. cleaning. Equipment has been constructed to continue experimental air classification, and the size fractions will be characterized by chemical analysis and electron microscopy.

The 50 to 400 mesh size fraction of the Upper Freeport Coal was processed through the Frantz separator at a $14^{\circ}$ transverse angle with the results shown in Table 10.2. This coal is considered an excellent candidate for magnetic processing, and the separation at the very high angle of $14^{\circ}$ attests to this. Color micrographs of the magnetic fraction show the pyrites as gold nuggets. 
Table 10.1

Coal

Identification

Size fraction

$\underline{B t u / 1 b} \quad \underline{\text { Ash } \%} \quad \underline{\text { Sulfur } \%}$

1

As pulverized

$>200$ mesh

11,112

20.7

1.21

200-400 mesh

$<400$ mesh

12,900

10.4

1.03

11,900

11.9

0.94

$<10 \mu$ air classified

9,700

30

0.8

5,515

51.3

1.4

2

As pulverized

$>200$ mesh

$\begin{array}{ll}11,572 & 20 \\ 12,361 & 16\end{array}$

2.2

200-400 mesh

$<400$ mesh

12,253

16.6

2.1

10,217

15.9

2.5

$<10 \mu$ sifted

7,384

27.8

2.3

7,665

42

2.5

$<10 \mu$ air classified

$\begin{array}{lll}13,874 & 6.23 & 1.65 \\ 14,083 & 5.47 & 1.70 \\ 14,072 & 5.41 & 1.81 \\ 12,892 & 8.90 & 1.65\end{array}$

As pulverized

100-200 mesh

200-400 mesh

$<10 \mu$. sifted

12,892

5.41

1.65

Coal 1 is pulverizer run from the Bull Run Power Plant Bowl Mil1; over $55 \%$ will pass 400 mesh.

Coal 2 is pulverizer run from the Y-12 Steam Plant Hammer Mil1; 39\% will pass 400 mesh.

Coal 3 is Upper Freeport pulverized at the X-10 Laboratory; 25\% will pass 400 mesh.

Table 10.2. Upper Freeport coal sieved to 50-400 mesh

\begin{tabular}{|c|c|c|c|c|}
\hline Fraction & Btu/1b & Ash \% & Sulfur \% & $\begin{array}{c}\text { Percent of } \\
\text { feed } \\
\end{array}$ \\
\hline Fced material & 13,924 & 5.73 & 1.78 & 100 \\
\hline Non-magnetic & 14,161 & 5.09 & 1.14 & 98.1 \\
\hline Magnetic & 5,207 & 50.14 & 15.77 & 1.9 \\
\hline
\end{tabular}




\title{
11. ATMOSPHERIC FLUIDIZED BED COMBUSTION DEMONSTRATION PLANT
}

\author{
C. B. Smith and J. E. Jones, Jr.
}

\subsection{Engineering Support}

No engineering support activities were performed during April.

\subsection{Technology Assessment}

M. Siman-Tov, T. G. Godfrey, R. E. Kuhlmann,

M. E. Lackey, and G. Samuels

\subsubsection{Task objectives}

The objectives of this task are: (1) to assess the AFBC technology and determine the existing data base as applicable to the proposed 200 MWe AFBC demonstration plant, (2) to identify the most critical problem areas and R\&D needs for the plant, and (3) to recommend priorities and schedule for the required $R \& D$ activities based on the needs identified during the assessment.

\section{2 .2 Status summary}

After some delay due to uncertainty regarding the AFBC demonstration plant program, the technology assessment is continuing to address the abuve ubjectives.

Review of the preliminary design and cost estimates for the AFBC demonstration unit from the three boiler manufacturers, B\&W, FCC, and $C E$, is now being completed. The comparative matrix of the demonstration plant design and operating parameters based on the data from the three design and cost estimates has been completed. The reviews of the design and cost estimate from Fluidized Combustion Company pointed out possible factors of concern including: the untried overbed fuel spreader feeder system, the high probability of freeboard burning of fines, the possibility of cyclic oxidizing-reducing atmospheres on heat exchanger equipment, and concern regarding sulfur capture due to freeboard combustion. The comparative analysis of the three designs given in the parameter matrix provides a point-by-point evaluation of all three.

Contacts to the various AFBC facilities and related agencies are in progress, and plans for visits are being finalized. Trip reports will be issued after each of the visits to summarize information gathered.

The table of contents for the final report is being revised. The $A F B C$ library is being continually updated with new material. 


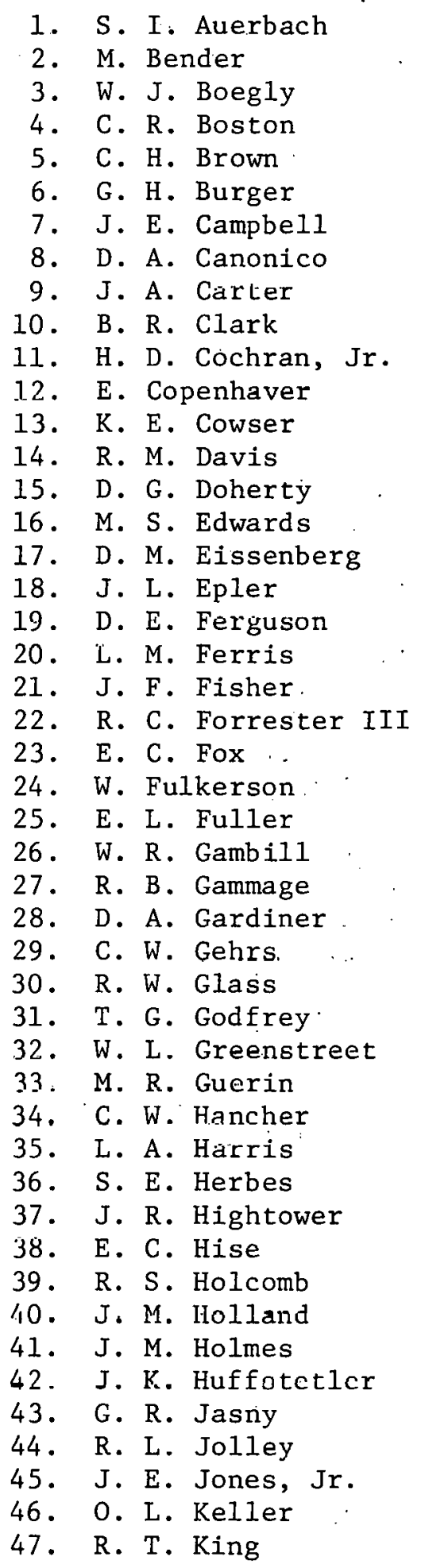

48... J. A. Klein

49. W. R. Laing

50. R. S. Livingston

51. R. E. MacPherson

52. A. P. Malinauskas

53. G. B. Marrow

54. C. J. McHargue

55-64. L. E. McNeese

65. J. P. Meyer

66. J. E. Mrochek

67. P. Nettesheim

68. B. N1emann

69. L. C. Oakes

70. G. E. Oswald

71. G. R. Peterson

72-73. T. W. Pickel

74. W. W. Pitt

75. H. Postma

76. D. E. Reichle

77. C. R. Richmond

78. B. R. Rodgers

79. M. W. Rosenthal

80. R. H. Ross

81. T. H. Row

82. W. L. Russell

83. R. Salmon

84. G. Samuels

85. C. D. Scott

86. D. S. Shriner

87. W. D. Shults

88. M. Siman-tov

89. S. P. N. Singh

90. C. B. Smith

91. G. P. Smith

92. I. Spiewak

93. R. L. Spore

94. J. B. Storer

95. R. A. Strehlow

96. H. E. Trammel1

97. D. B. 'I'rauger

98. W. C. Ulrich

99. P. R. Vanstrum

100. J. S. Watson

101. J. R. We1r

102. P. R. Westmoreland

103. M. K. Wilkinson

104. L. V. Wilson 
105. R. G. Wymer

106. E. L. Youngblood

107. C. S. Yust

108. S. Alpert (Consultant)

109. H. Beuther (Consultant)

110. M. Semchyshen (Consultant)

111. H. W. Sternberg (Consultant)
112. C. Streed (Consultant)

113. Patent office

114. Laboratory Records - RC

115-120. Laboratory Records

121-124. Central Research Library

125. Document Reference Section

\section{EXTERNAL DISTRIBUTION}

DOE-Oak Ridge Operations

126. Research and Technical Support Division

DOE-Denver Project Office, Suite 211, 1075 S. Yukon Street, Lakewood, CO 80226

127. A. A. Hagen

DOE-FE, Washington, DC

128. W. Bakker

129. E. K. Bastress

130. J. D. Batchelor

131. J. A. Belding

132. T. Beresovski

133. L. M. Burman

134. E. L. Burwell

135. E. L. Clark

136. N. P. Cochran

137. R. C. Corey

138. T. Cox

139. C. W. Di Bella

140. P. Duhamel

1.41. J. Forst

142. H. Franke1

143. S. I. Freedman

144. D. Garrett

145. W. S. Harmon

146. H. Jones

149. C. W. Knudsen

150. T. K. Lau

151. W. G. McDaniel

152. C. Miller

153. J. A. Nardella

154. M. Neuworth

155. E. S. Pierce

156. H. E. Podall

157. J. L. Powell

158. M. Reilly

159. J. Shen

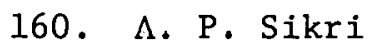

161. J. Smith

162. D. K. Steveñs

163. W. E. Warkne

164. J. W. Watkins

165. H. L. Weisenfeld

166. D. O. Webb

147. L. M. Joseph

167. P. R. Wieber

148. L. Kindley

DOE-Environment, Washington, DC

168. N. F. Barr

169. R. M. Jimeeon

170. W. E. Mott

171. R. W. Wood 
Department of Housing and Urban Development, 4517 th St., S.W., Washington, DC 20410

172. G. S. Leighton

173. J. H. Rothenberg

University of Kentucky, Institute for Mining and Minerals Research, 213 Bradley Hall, Lexington, KY 40506

174. Theresa Wiley, Institute Librarian

175. 0. J. Hahn

176. J. K. Shau

National Science Foundation, 1800 G Street, N.W., Washington, DC 20550

177. Robert Rabin

178. Charles B. Sedman, U.S. Environmental Protection Agency, Research Triangle Park, NC 27711

179. N. S. Boodman, Section Supervisor, U.S. Steel Corporation Applied Research Laboratory, 125 Jamison Lane, Monroeville, PA 15146

180-191. Pittsburgh Energy Research Center, Attention: Director for J. 0. Barreca, 4800 Forbes Ave., Pittsburgh, PA 15213

192-197. The Director, Morgantown Energy Research Center, P. 0. Box 800, Morgantown, WV 26506

198. Tetra Tech, Inc., 1911 N. Ft. Myer Drive, Suite 601, Arlington, VA 22209, Attention: Walter McGough, Jr.

199. Cameron Engineers, Attention: Gary L. Baughman, 1315 South Clarkson St., Denver, CO 80213

200. Steven R. Smith, Tennessee Valley Authority, 1230 CUBB-C, Chat tanooga, TN 37401

201. Manville J. Mayfield, Tennessee Valley Authority, 1320 CUBB-C, Chat tanooga, TN 37401

202. Randy M. Cole, Tennessee Valley Authority, 1320 CUBB-C, Chat tanooga, TN 37401

203. Jack L. Gregory, Project Manager, TRW Energy Systems, 7600 Colshire Drive, McClean, VA 22101

204. F. N. Peebles, Dean of Engineering, University of Tennessee, Knoxville, TN 37916

205. Frank P. Rarannwsk. Crystal Square 4, Suite 310, Jefferson Davis Highway, Arlington, VA 22202

206. William C. Corder, Bechtel National, Inc., Engineers-Constructors, Fifty Beale Street, Post Office Box 3965, San Francisco, CA 94119

207. Donald C. Ihomas, Tennessee Valley Authority, 1360 Commerce Union Bank Building, Chattanooga, TN 37401

208. Kenneth P. Lue Phang, Developmental Engineering Staff, Tennessee Valley Authority, 220 Liberty Building, Knoxvi]1e, TN 37902

209. W. R. Siegart, Texaco Inc., 2000 Westchester Avenue, White Plains, NY 10650

210. Y. A. Liu, Department of Chemical Engineering, Auburn University Auburn, AL 36830

211-237. Technical Information Center 